\title{
Dohodovne nejednakosti i redistributivne preferencije u Hrvatskoj i zemljama EU-a: makroanaliza
}

\section{ZORAN ŠUĆUR *}

Studijski centar socijalnog rada

Pravni fakultet Sveučilišta u Zagrebu

Zagreb, Hrvatska
Izvorni znanstveni rad

UDK: 364.013(497.5):330.566.2

doi: $10.3935 /$ rsp.v28i2.1700

Primljeno: siječanj 2020.

U radu se analizira veza između dohodovnih nejednakosti i redistributivnih preferencija. Glavni su ciljevi rada: utvrditi u kojoj su mjeri stvarne dohodovne nejednakosti povezane s redistributivnim preferencijama, koji su korelati redistributivnih preferencija na makrorazini te koje mehanizme redistribucije preferiraju građani u zemljama EU-a. Kao izvori podataka o redistributivnim preferencijama korišteni su agregirani podaci iz dvaju specijalnih istraživanja Eurobarometra (2010. i 2018.), dok su makrostatistički pokazatelji uzeti iz Eurostatove baze podataka. U radu su korištene bivarijatne korelacijske analize, linearna regresija $i$ klaster analiza. Opći je nalaz da su visoke redistributivne preferencije prisutne u gotovo svim zemljama EU-a. Izgleda da rast dohodovnih nejednakosti nije ključni čimbenik visoke razine redistributivnih preferencija, već je to percepcija dohodovnih nejednakosti i osjetljivost građana na ekonomske nejednakosti. Građani u zemljama EU-a često pogrešno percipiraju razinu nejednakosti u društvu i svoje mjesto na dohodovnoj ljestvici. Ispitanici iz postsocijalističkih zemalja imaju veću »averziju « prema dohodovnim nejednakostima $i$ žele veću ulogu države u redistribuciji i društvenom životu. Stanovnici EU-a podržavaju sve ključne mehanizme dohodovne redistribucije (porezi, obrazovanje, socijalna zaštita i minimalna plaća), ali najveću potporu daju poreznom sustavu i progresivnom oporezivanju bogatijih, dok je najviše dilema vezano za potpuno besplatno obrazovanje.

Ključne riječi: dohodovne nejednakosti, redistributivne preferencije, EU, mehanizmi redistribucije, socijalna pravednost

\section{UVOD}

Ekonomske nejednakosti nalazimo u svim modernim i predmodernim društvima i kao takve izgledaju neizbježne i nužne za ekonomski i društveni razvoj. Pokušaji da se izgrade društva bez ekonomskih nejed- nakosti u pravilu su završavali u totalitarističkim režimima. Međutim, vrlo je teško postići društveni konsenzus oko prihvatljive razine ekonomskih nejednakosti. Prevladava sve više mišljenje da ekonomske nejednakosti u posljednjim desetljećima

* Zoran Šućur, Studijski centar socijalnog rada, Pravni fakultet Sveučilišta u Zagrebu / Department of Social Work, Faculty of Law, University of Zagreb, Nazorova 51, 10000 Zagreb, Hrvatska / Croatia, zsucur@pravo.hr 
rastu u europskim i zapadnim zemljama i da su poprimile neprihvatljive i društveno štetne razmjere. Zato nije čudno da su nejednakosti u dohotku ili bogatstvu postale jednom od ključnih ekonomskih, socioloških i socijalnopolitičkih tema (Piketty, 2014.; Dabla-Norris i sur., 2015.; Kenworthy i Pontusson, 2005.; Tilly, 2003.; Atkinson i sur., 2017.; Solt, 2008.; Wilkinson i Pickett, 2006.). Pritom treba upozoriti da je većina istraživanja o nejednakostima usmjerena na nejednakosti koje proizlaze iz raspodjele dohotka jer je ukupno bogatstvo teže precizno mjeriti.

Ekonomske nejednakosti postale su aktualna istraživačka tema jer se smatra da njihov rast dovodi do niza negativnih socijalnih, ekonomskih i drugih posljedica: podrivaju ekonomski rast, povećavaju rizik siromaštva, produbljuju nejednakosti u narednim generacijama, uzrokuju polarizacije i fragmentaciju društva (Dabla-Norris i sur., 2015.; Medgyesi, 2013.). Dabla-Norris i sur. (2015.) ističu negativne efekte dohodovnih nejednakosti na ekonomski rast: kada se poveća udio dohotka gornjih $20 \%$ stanovništva za $1 \%$, ekonomski rast se smanji za $0,08 \%$, a kada se poveća udio dohotka donjih $20 \%$ stanovništva za $1 \%$, ekonomski se rast poveća za $0,38 \%$. Nejednakosti negativno utječu na socijalnu koheziju, na razinu suradnje i povjerenja između članova društva, ali i na zdravlje populacije (Wilkinson i Pickett, 2006.; Rözer i Volker, 2016.). Wilkinson i Pickett (2006.) su u svojoj metastudiji analizirali preko 160 radova o odnosu ekonomskih nejednakosti i zdravlja stanovništva te ustanovili da $70 \%$ studija potvrđuje da je zdravlje lošije u društvima $\mathrm{s}$ većim nejednakostima.

Osim toga, visoke ekonomske nejednakosti mogu imati i političke posljedice. Solt (2008.) ukazuje na to da ekonomke nejednakosti smanjuju interes za politiku i političke rasprave te reduciraju sudjelovanje svih skupina na izborima, osim onih najbogatijih. Gimpelson i Treisman (2018.) ističu da je u autokracijama koje imaju veće nejednakosti veća i vjerojatnost za pojavu revolucija, građanskih ratova i političkog nasilja. Izražene nejednakosti u distribuciji dohotka ili bogatstva stvaraju i veći potencijal za kolektivno nasilje i veću vjerojatnost da se ovaj potencijal za nasilje transformira u stvarno nasilje (Gurr, 1970.). Prema tome, velike nejednakosti ne doprinose demokratizaciji društva.

Neki ekonomske nejednakosti povezuju $\mathrm{s}$ evolucijom političkih režima. Ako elite u autokratskim režimima predviđaju da će demokracija rezultirati velikom redistribucijom, nastojat će spriječiti demokratizaciju. Odnos između demokratizacije i ekonomskih nejednakosti, kako navode Gimpelson i Treisman (2018.), ima oblik obrnutog slova U: demokracija je malo vjerojatna kada su nejednakosti prevelike ili premale (npr. ako su nejednakosti preniske, onda će siromašniji slabo profitirati od oporezivanja bogatih). No, nije empirijski potvrđeno da nejednakosti nužno potiču političko nasilje jer veza između ekonomskih nejednakosti i redistribucije nije direktna, već je posredovana vjerovanjima o pravičnosti distribucije, šansama za mobilnost i drugim socijalnim normama.

Ako su nejednakosti velike u nekom društvu, opravdano se postavlja pitanje je li ispravno govoriti o »bogatim « nacijama tamo gdje je nacionalno bogatstvo kombinirano s velikim osobnim siromaštvom. Time nejednakosti neizbježno potiču rasprave o pravednoj raspodjeli dohotka i bogatstva i eventualnoj redistribuciji tih materijalnih resursa.

Problem redistribucije postaje važan u suvremenim društvima i zbog toga što se povećava udio javne potrošnje i socijalnih transfera u BDP-u. Alesina i la Ferrara (2005.) navode da je 1960. godine prosječni udio transfera vlade u BDP-u u zemljama OECD-a iznosio 8\%, a udio koji se odnosi na pružanje javnih dobara i usluga $15 \%$. Početkom 21. stoljeća udio za transfere se 
udvostručio (16\%), a onaj za javna dobra i usluge tek je porastao za dva postotna boda (17\%). To znači da udio BDP-a za transfere i socijalne troškove raste, dok potrošnja države uglavnom stagnira. Zbog toga, odnos između ekonomskih nejednakosti i redistributivnih preferencija postaje sve češće tema znanstvenih radova.

Nastavak rada sastoji se od pet poglavlja i zaključka. Prvo poglavlje sadrži pregled istraživanja o odnosu između dohodovnih nejednakosti i redistributivnih preferencija, prvenstveno u europskim i zapadnim zemljama, a drugo osvrt na istraživanja nejednakosti i redistribucije u Hrvatskoj. Zatim su u metodološkom dijelu rada navedeni ciljevi rada, izvori podataka i varijable. Iza toga slijede rezultati rada, rasprava i zaključak.

\section{DOHODOVNE NEJEDNAKOSTI I REDISTRIBUTIVNE PREFERENCIJE: PREGLED ISTRAŽIVANJA}

Prva je logična pretpostavka da su redistributivne preferencije povezane sa stvarnim dohodovnim nejednakostima. Međutim, odnos između stvarnih nejednakosti i redistributivnih preferencija nije linearan (Toth i Keller, 2011.): kada su agregatne nejednakosti u društvu nešto veće, više su i redistributivne preferencije svih klasa, ali kada su nejednakosti vrlo visoke, redistributivne preferencije se mogu smanjivati. Gotovo sva istraživanja u europskim i zapadnim zemljama, kao i ona izvan Europe (npr. Kim i sur., 2018.), utvrdila su da su za redistributivne preferencije znatno važnije percepcije nejednakosti nego stvarne nejednakosti (Fatke, 2018.; Engelhardt i Wagener, 2014., Niehues, 2014.; Medgyesi, 2013.; Gimpelson i Treisman, 2018.; Kuhn, 2016.; Kuziemko i sur., 2015.). Drugim riječima, nema značajne korelacije između stvarne distribucije dohotka i percepcije dohodovnih nejednakosti. Ista razina do- hodovnih nejednakosti može biti različito percipirana u različitim društvima, što ovisi o socijalnim nejednakostima, dominantnim socijalnim normama, povijesnom nasljeđu i sl. Istina, kada stvarne nejednakosti rastu, u pravilu raste nezadovoljstvo razinom nejednakosti. Međutim, utjecaj rasta realnih nejednakosti na nezadovoljstvo je slab. Prema nalazima Medgyesija (2013.), rast Ginijeva koeficijenta za 10 postotnih bodova dovodi tek do neznatnog rasta nezadovoljstva nejednakostima od 0,5 postotnih bodova. Štoviše, primjer Velike Britanije pokazuje da potpora redistribuciji može padati iako nejednakosti rastu (Georgiadis i Manning, 2012.), uz širenje negativnih stavova prema siromašnima (Cavaille i Trump, 2015.). Ovakvi trendovi objašnjavaju se time da slabi afinitet srednjih slojeva prema siromašnima. Ako raste distanca između srednjih i donjih (siromašnijih) slojeva, smanjuje se potpora brojne srednje klase redistribuciji. To može biti rezultat imigracije i rasta etničke heterogenosti, zbog čega se povećava udio manjinskih skupina među siromašnima. Alt i Iversen (2017.) nalaze da potpora srednje klase redistribuciji raste ako je tržište rada manje segmentirano. Prema pristupu socijalne distance, da bi se povećala potpora redistribuciji u korist siromašnih, treba mijenjati stavove većine prema manjinskim skupinama kroz obrazovni sustav.

$\mathrm{Na}$ redistributivne preferencije utječe visina trenutnog dohotka. Polazi se od pretpostavke da ce relativno bogatije osobe prihvaćati veće nejednakosti i slabije podržavati redistribuciju iz koje izvlače manje koristi. Prema teoremu medijalnog birača (Meltzer i Richard, 1981.), ako glasači raspolažu dohotkom koji je ispod prosjeka ili medijana, oni će podržavati veću redistribuciju kroz socijalnu državu jer će imati koristi od socijalnih programa koji se financiraju na progresivan način (pojedinci s većim dohotkom plaćaju više doprinosa ili poreza, a manje koriste naknade). Što je medijan dohotka niže od prosječnog dohot- 
ka, bit će izraženija želja za redistribucijom. Međutim, provjere ovih teza urodile se nekoherentnim i kontradiktornim rezultatima (Kenworthy i McCall, 2008.; Milanovic, 2000.). Na primjer, iako su nejednakosti u SAD-u više nego u EU ili zemljama Europe, razina redistribucije je manja. $S$ druge strane, europske zemlje imaju niže dohodovne nejednakosti, ali znatno razvijeniju i izdašniju socijalnu državu. Stoga je model medijalnog glasača nadopunjen tezom o utjecaju očekivane uzlazne mobilnosti na redistribuciju. Međutim, ni ovako prošireni model ne objašnjava posve distributivne razlike među pojedinim zemljama. Prema Niehues (2014.), Njemačka i Švicarska imaju slične dohodovne nejednakosti i slične pokazatelje mobilnosti, ali i dalje postoje velike razlike u državnoj redistribuciji.

Prema teoremu medijalnog birača, na odnos prema redistribuciji utječe, prije svega, vlastiti ekonomski interes (koji obuhvaća ne samo dohodak i bogatstvo, već i nečiju tržišnu i klasnu poziciju). Međutim, brojni autori pokazuju da je samo pojedinačni ekonomski interes slab prediktor odnosa prema redistribuciji jer na taj odnos utječe socijalni kontekst koji podrazumijeva klasnu, rasnu, religijsku i drugu pripadnost pojedinca (Evans, 2000.; Fong, 2001.; Luttmer, 2001.; Glaeser i Ward, 2006.; Toth i Keller, 2011.; Medgyesi, 2013.). To znači da je socijalni identitet jedan od čimbenika koji također utječu na distributivne stavove: pojedinac brine ne samo o svom interesu nego i o interesu grupe kojoj pripada. Klor i Shayo (2010.) nalaze da grupna identifikacija značajnije utječe na redistributivne preferencije nego »averzija prema nejednakosti«. U eksperimentu koji su proveli pokazalo se da pojedinci koji su osobno bogati glasuju za višu razinu redistribucije kada je njihova grupa relativno siromašnija i obrnuto, glasuju za manje redistribucije kada im je grupa bogatija, iako su oni relativno siromašniji. Izgleda da su siromašniji pojedinci spremni žrtvovati svoje ekonomske probitke radi povećanja prosječne koristi svoje skupine. S druge strane, kada bogatiji pojedinci pripadaju siromašnijim skupinama, raste vjerojatnost da će podržati veće poreze pod uvjetom da ekonomski troškovi takve mjere nisu za njih preveliki.

Vrijednosne orijentacije također imaju utjecaja na prihvaćanje određene razine dohodovnih nejednakosti. Na primjer, pojedinci koji prihvaćaju egalitarizam općenito će preferirati niže nejednakosti, dok libertarijanci mogu prihvaćati bilo kakve nejednakosti ako su one posljedica slobodne razmjene. Odnos prema nejednakostima može proizlaziti iz iskustava življenja u socijalnim režimima koji promiču određeni koncept socijalne pravde, koji pojedinci internaliziraju kroz institucije i ideologiju režima. Različite tradicije i nasljeđa mogu biti povezani s redistributivnim preferencijama. U zemljama s protestantskom tradicijom može se očekivati veća tolerancija prema nejednakostima jer protestantizam u većoj mjeri nego katolicizam naglašava individualnu odgovornost i postignuća. Povijesno nasljeđe vezano za život $\mathrm{u}$ socijalističkom ili komunističkom sustavu također može utjecati na stav prema redistribuciji (Gijsberts, 2002.; Murthi i Tiongson, 2008.).

Teza da relativna dohodovna pozicija pojedinca utječe na stav prema distribuciji ima smisla ako ljudi znaju točnu informaciju o svom položaju. Problem je u tome što ljudi često pogrešno procjenjuju vlastito mjesto na distributivnoj ljestvici (Cruces i sur., 2013.; Karadja i sur., 2017.; Fernandez-Albertos i Kuo, 2018.; Knell i Stix, 2017.). To nije začudno jer se često i stručnjaci žale na nedostatak ili nepouzdanost podataka o distribuciji dohotka i posebice o distribuciji ukupnog bogatstva. U jednom istraživanju u Španjolskoj samo je $14 \%$ ispitanika točno identificiralo svoj decil u dohodovnoj distribuciji (Gimpelson i Treisman, 2018.). Autori su došli do zaključka da je udio onih koji uspijevaju identificirati stvarni oblik dohodovne distribucije u svojoj zemlji tek 
nešto veći od posve slučajnog izbora. Ispitanici, ne samo da imaju pogrešne percepcije svog položaja, već često imaju iskrivljene informacije o zaradama onih koji su dobro ili slabo plaćeni ili, na primjer, o udjelu bogatstva najbogatijih u društvu. Cruces i sur. (2013.) te Knell i Stix (2017.) konstatiraju da pojedinci s nižim dohotkom podcjenjuju, a oni s visokim dohotkom precjenjuju svoje mjesto na dohodovnoj ljestvici. Osobe s niskim dohotkom zamišljaju dohodovnu distribuciju u obliku »piramide«, a oni s višim dohotkom u obliku »vaze« ili »romba«. Autori zaključuju da je to povezano s referentnim grupama i relativnim položajem pojedinca unutar ovih grupa. Na primjer, ispitanici koji su imali prijatelje iz različitih socijalnih i dohodovnih skupina manje su bili skloni pristranim ocjenama. Ovakve pogrešne percepcije onda utječu na redistributivne preferencije. Cruces i sur. (2013.) proveli su eksperiment u kojem su ispitanike eksperimentalne skupine informirali o razlici između njihove percipirane i stvarne dohodovne pozicije. Nakon što su bili suočeni s pogreškama u percepciji, ispitanici koji su precjenjivali svoj položaj tražili su više redistribucije u odnosu na ispitanike kontrolne skupine. Međutim, istraživanje u Švedskoj (Karadja i sur., 2017.) pokazalo je da dobivanje točne informacije o svom položaju u distribuciji utječe na stavove ispitanika koji su desno od centra, a da uopće ne utječe na pojedince koji nemaju desne političke orijentacije. Osim toga, objektivniju sliku o svom distribucijskom položaju imali su obrazovaniji pojedinci, oni koji su bolje medijski informirani te oni koji se nedavno doživjeli uzlaznu mobilnost. Prema nalazima Cruces i sur. (2013.), informiranost o vlastitom položaju povećava potporu općim aktivnostima vlade protiv nejednakosti, ali ne nužno i potporu specifičnim mjerama, kao što su, na primjer, povećanje poreza. S druge strane, Fernandez-Albertos i Kuo (2018.) zaključuju da točno informiranje ispitanika o njihovoj stvarnoj dohodovnoj poziciji utječe na njihovu podršku progresivnom poreznom sustavu. Ako pojedinac nakon informiranja sazna da se nalazi u najsiromašnijem kvintilu, vjerojatno će podržati i veću razinu porezne progresivnosti. Isto tako, ako pojedinci koji su vjerovali da su siromašni prije informiranja nakon informiranja saznaju da su još siromašniji, poduprijet će veću poreznu progresivnost (međutim, sličan efekt nije pronađen među onima kojima su vjerovali da su bogati i saznali nakon informiranja da su još bogatiji).

Na potporu redistribuciji utječe ne samo sadašnji, već i budući dohodak. Na primjer, Alesina i la Ferrara (2005.) pokazali su da Amerikanci uzimaju u obzir svoje buduće šanse da povećaju dohodak prilikom procjene dobitaka i gubitaka redistribucije. Što je veća vjerojatnost za povećanje budućeg dohotka i ulaska u gornje dohodovne decile $\mathrm{u}$ idućih pet godina, to je manja sklonost redistribuciji. Također, oni koji vjeruju u rad i zasluge ili vjeruju da je SAD zemlja jednakih šansi, manje su skloni redistribuciji. Benabou i Ok (2001.), Engelhardt i Wagener (2014), Rainer i Siedler (2008.) također ističu važnost uzlazne mobilnosti. Piketty (1995.) razvija model učenja prema kojem postoji povezanost između socijalne mobilnosti, vjerovanja o tome utječu li sreća ili zasluge na dohodak i redistributivnih preferencija. Ako se društveni uspjeh više pripisuje sreći nego radu i uloženim naporima, bit će i veća želja za redistribucijom. Dakle, neće svi trenutno siromašni ili oni s nižim dohodcima podržati politiku koja se zalaže za veće oporezivanje viših dohodaka ako očekuju uspon na društvenoj ljestvici, jer bi ih takva mjera mogla negativno pogoditi (Benabou i Ok, 2001.). Očekivanja o uzlaznoj mobilnosti ne moraju se bazirati na točnim pretpostavkama, već na percepciji takve mobilnosti. Osim uzlazne mobilnosti, na distributivne preferencije utječe i silazna mobilnost. Na primjer, oni koji očekuju pogoršavanje svog položaja na ljestvici zagovarat će češće snižavanje poreza za 
siromašne i povećanje za bogate. Rainer i Siedler (2008.) čak smatraju da je strah od silazne mobilnosti tješnje povezan s redistributivnim preferencijama nego šanse za uzlaznu mobilnost.

Brojni individualni čimbenici, osim dohotka i bogatstva, utječu na stav prema redistribuciji, kao što su: spol, dob, obrazovanje, profesionalni i zaposlenički status (Popitz, 2018.; Alesina i la Ferrara, 2005.). U istraživanju Alesine i la Ferrare (2005.) pronađeno je da su mlađi ljudi, žene i Afroamerikanci skloniji redistribuciji, a manje skloni obrazovaniji pojedinci. Bračni status i religijska pripadnost nisu se pokazali značajnim ili su imali vrlo slab utjecaj. Također, oni koji su spremniji preuzeti rizik (npr. samozaposleni) manje su voljni podržati redistribuciju. Iskustva nezaposlenosti također utječu na stav prema redistribuciji, kao i altruističke orijentacije (želja za pomaganjem drugima). Ako pojedinci vjeruju da su uzroci siromaštva individualno-obiteljske prirode (lijenost, loša sreća), manje će podržavati redistribuciju (Toth i Keller, 2011.).

\section{ISTRAŽIVANJA O EKONOMSKIM NEJEDNAKOSTIMA I REDISTRIBUCIJI U HRVATSKOJ}

Vrlo je malo istraživanja koja se bave temom dohodovnih nejednakosti, redistribucije ili njihovim odnosom u Hrvatskoj. To se može kazati kako za socijalističko razdoblje (prije 1990.) tako i za tranzicijsko i posttranzicijsko razdoblje (nakon 1990. godine). Kao što navodi Nestić: »U socijalističkom razdoblju razloge za to treba tražiti u neugodnosti teme za tada etablirane polit-ekonomske krugove. Pozornost je mnogo više bila usmjerena na raspodjelu dohotka između industrijskih grana i gru- pacija. Analiza raspodjele blagostanja stanovništva bila je ograničena na pojedinačne akademske doprinose, bez kontinuiranog istraživanja« (Nestić, 2002.: 595). Stoga ne čude tek naknadni pokušaji da se procijene nejednakosti u određenim periodima socijalizma. Polazeći od podataka iz anketa o potrošnji kućanstava, koje su se provodile u bivšoj Jugoslaviji svakih pet godina, Nestić (2002.) dolazi do zaključka da su od sredine 1970-ih do danas prisutne tek male varijacije u razini nejednakosti ako ih mjerimo Ginijevim koeficijentom. Tako su se ekonomske nejednakosti smanjivale od 1973. (Ginijev koeficijent $=0,30$ ) do 1983. (Ginijev koeficijent $=0,27$ ), a zatim rastu u drugoj polovici 1980-ih i u 1990-ima (Ginijev koeficijent u 1988. =0,29, a u 1998. godini $=0,30) .{ }^{1}$ Tijekom tranzicije, dogodio se tek umjereni ili blagi rast nejednakosti, što je bilo protivno prevladavajućim percepcijama o vrlo snažnom porastu nejednakosti. Ovaj se blagi rast nejednakosti može tumačiti padom udjela plaća, a rastom udjela mirovina i općenito socijalnih transfera u ukupnim dohocima.

Međutim, u socijalističkom razdoblju tema distribucije i redistribucije bila je u središtu socioloških radova Josipa Županova. U više svojih radova on se bavio temom radikalnog egalitarizma ili »egalitarnog sindroma« (Županov, 1977., 1993., 1995., 2011.). Županov izdvaja egalitarizam kao dominantnu društvenu vrijednost hrvatskog socijalističkog društva, odnosno govori o »egalitarnom sindromu« koji obuhvaća sedam komponenti: ideja ograničenog dobra, redistributivna etika, opsesija o privatniku, egalitarna raspodjela, antiprofesionalizam, intelektualna uravnilovka i antiintelektualizam. Njegovo je stajalište da različite sastavnice egalitarnog sindroma negativno utječu na ekonomski i socijalni razvoj. Me-

${ }^{1}$ U radu Severa i Drezgića (2003.) navode se znatno viši Ginijevi koeficijenti za razdoblje od 1995. do 2001. (od 0,37 do 0,41), ali je upitna pouzdanost ovih podataka s obzirom na nejasnu definiciju dohotka u spomenutom radu. 
đutim, koncept egalitarnog sindroma nikada nije bio empirijski potvrđen u razdoblju socijalizma, što je i jedan od razloga novijih preispitivanja ovog koncepta (Dolenec, 2014.). Ipak, nedavna testiranja ovog koncepta potvrdila su postojanje pet od sedam dimenzija egalitarnog sindroma (Štulhofer i Burić, 2015.) te je pronađena pozitivna korelacija između egalitarnog sindroma i obrazovanja, zanimanja i življenja u ruralnom/ urbanom okruženju, a negativna korelacija sa stupnjem županijskog razvoja, BDP-om, indeksom kompetitivnosti ili udjelom novog poduzetništva.

Valja istaknuti da je Županov predviđao jačanje radikalnog egalitarizma nakon 1990. jer je radikalni egalitarizam »najprimjerenija filozofija u vrijeme bijede i oskudice, u vrijeme relativne, a pogotovo apsolutne deprivacije « (Županov, 2011.: 150). Prema tome, moguće je očekivati da bi »socijalističko nasljeđe« (Murthi i Tiongson, 2008.) moglo igrati važnu ulogu u potpori redistribuciji u Hrvatskoj. Dva čimbenika utječu na to da postsocijalističke zemlje imaju snažniju potporu većoj dohodovnoj jednakosti nego zemlje bez socijalističkog nasljeđa. Prvo, bivše socijalističke zemlje imale su niže ekonomke nejednakosti nego zapadne zemlje s tržišnom ekonomijom, pa su građani u postsocijalističkim zemljama osjetljiviji na bilo kakva povećanja nejednakosti. S druge strane, jedan od uobičajenih kanala redistribucije dohotka jest onaj $\mathrm{kroz}$ programe i mehanizme države. Građani nekadašnjih socijalističkih zemalja iskazuju veće povjerenje u državu kao jamca mini- malne sigurnosti i aktera redistribucije nego zapadne zemlje. ${ }^{2}$

Procjenjujući preferencije prema dohodovnoj jednakosti na podacima World Values Survey (WVS) 1999.-2001., Murthi i Tiongson (2008.) pronašli su da je $\mathrm{Hr}-$ vatska, uz Sloveniju i Rumunjsku, imala najveću potporu dohodovnim jednakostima među postsocijalističkim zemljama. Čak i kada se ograničimo samo na donji kvartil, u kojem je općenito najveća podrška dohodovnoj jednakosti, opet je u skupini zemalja s najvećom potporom jednakosti Hrvatska, uz Sloveniju, Rumunjsku i Litvu.

Određeni uvid u odnos hrvatskih građana prema dohodovnim (ne)jednakostima moguće je dobiti iz istraživanja European Values Study (EVS), u kojem je Hrvatska sudjelovala u tri vala: 1999., 2008. i 2017. (vidi Baloban, Črpić i Ježovita, 2019.; Baloban, Nikodem i Zrinščak, 2014.). Vidljivo je iz Slike 1. da se Hrvatska nalazi među nekoliko zemalja s najvećom potporom egalitarnoj raspodjeli. Veću potporu dohodovnoj jednakosti imale su samo Slovenija, Rumunjska (u dva od tri EVS vala) te Njemačka i Austrija u jednom EVS valu. Međutim, u odnosu na spomenute zemlje, Hrvatska ima najmanje varijacija u potpori dohodovnoj jednakosti (u sva tri vala potpora je iznosila između $28 \%$ i $35 \%$ ). U preostale četiri zemlje potpora je u 2017. bila niža od $20 \%$ (posebice su velike varijacije u potpori dohodovnoj jednakosti u Rumunjskoj: $48 \%$ u 1999. i $50 \%$ u 2008., ali manje od $12 \%$ u 2017.).

\footnotetext{
${ }^{2}$ Istina, i u nekim zapadnim zemljama nalazimo visoku razinu povjerenja u ulogu države u redistribuciji ili u pružanju usluga kao, na primjer, u skandinavskim ili nekim južnoeuropskim zemljama (Murthi i Tiongson, 2008.).
} 
Slika 1.

Potpora dohodovnoj jednakosti u zemljama EU-a (temeljem EVS-a)*

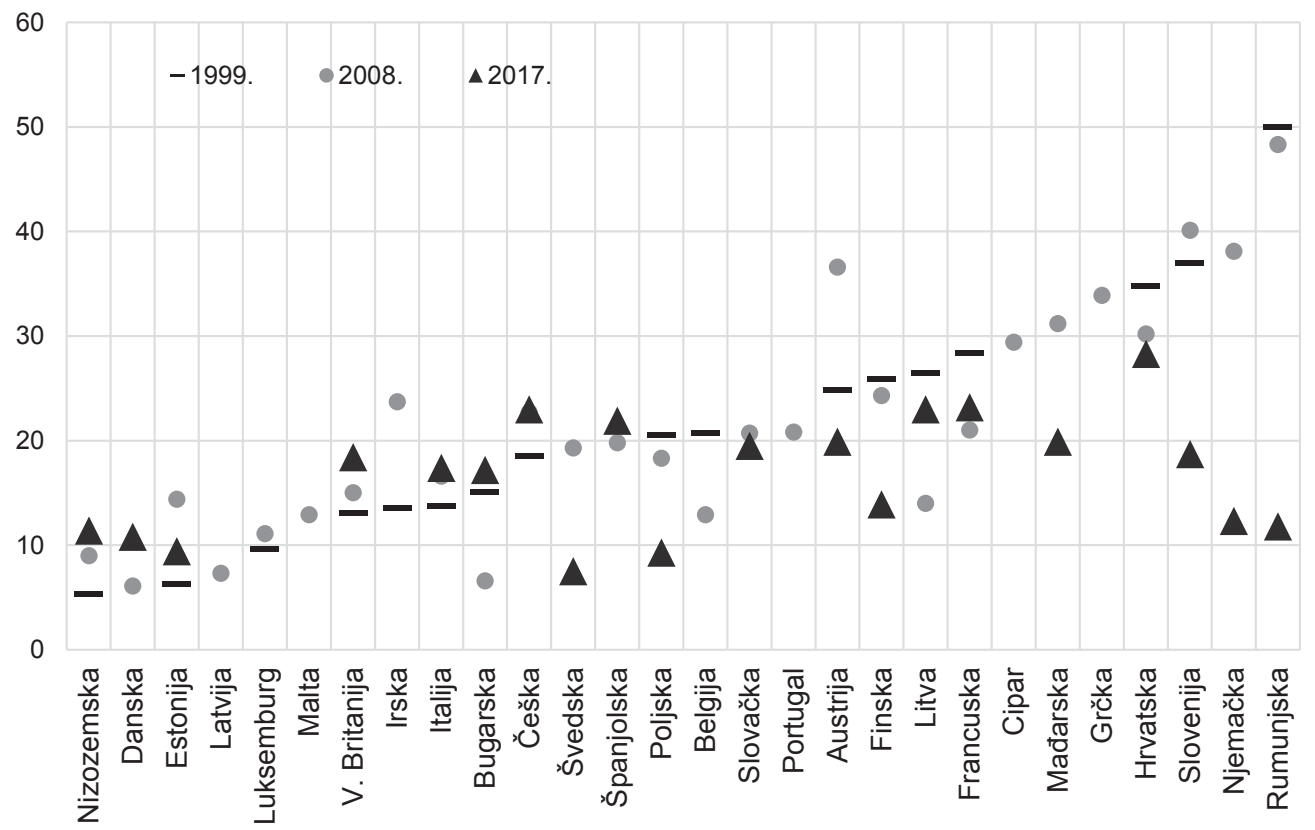

* Ispitanici su izražavali stupanj slaganja s tvrdnjom koja se tiče dohodovnih jednakosti na ljestvici od 10 stupnjeva, gdje je 1 značio: »Treba smanjiti razlike u plaćama kako bi svi imali podjednako«, a 10 - »Treba povećati razlike u plaćama kako bi se povećalo zalaganje pojedinaca«. Postoci na slici predstavljaju zbroj postotaka za stupnjeve 1 i 2 koji označavaju najveći intenzitet slaganja s tvrdnjom da treba smanjiti razlike u plaćama kako bi svi imali podjednako.

Izvor: autorovi izračuni temeljem baze podataka dostupne na: https://zacat.gesis.org/webview/index. jsp?object=http://zacat.gesis.org/obj/fCatalog/Catalog5.

\section{METODOLOGIJA ISTRAŽIVANJA Ciljevi rada}

Ciljevi rada su sljedeći:

1) utvrditi kakvi su trendovi dohodovnih nejednakosti u zemljama EU-a u zadnja dva desetljeća te kako ispitanici zamišljaju dohodovnu strukturu u svojim zemljama

2) u kojoj je mjeri razina stvarnih dohodovnih nejednakosti povezana s redistributivnim preferencijama i koji su korelati redistributivnih preferencija na makrorazini
3) koji su potencijalni mehanizmi redistributivne politike te koje mehanizme preferiraju građani u zemljama EU-a.

\section{Izvori podataka i vremenski okvir analize}

$\mathrm{U}$ analizi podataka o redistributivnim preferencijama korišteni su agregirani podaci iz dvaju specijalnih istraživanja Eurobarometra: prvo je istraživanje provedeno 2010. (Eurobarometer, 2010.), a drugo 2017. godine (Eurobarometer, 2018.). Oba istraživanja sadrže određeni skup istovjetnih 
ili sličnih varijabli koje se odnose na nejednakosti i distributivne preferencije, što omogućuje usporedbu podataka u dvije vremenske točke, s tim da istraživanjem iz 2010. nije bila obuhvaćena Hrvatska jer tada nije bila članica EU-a. Istraživanje iz 2010. sadrži opsežnije podatke o poželjnim mehanizmima redistribucije nego istraživanje provedeno 2017.

Kako bi se utvrdili korelati redistributivnih preferencija na makrorazini država članica (različiti makrostatistički pokazatelji), korišteni su podaci iz Eurostatove baze podataka ili iznimno podaci iz nacionalnih baza podataka.

\section{Varijable i postupak}

Redistributivne preferencije mjerene su preko tvrdnje: »Vlada treba poduzeti mjere da smanji razlike u dohotku«. Ispitanici su stupanj slaganja s tvrdnjom izražavali na Likertovoj ljestvici od pet stupnjeva: 1 Potpuno se slažem, 2 - Slažem se, 3 - Niti se slažem niti ne slažem, 4 - Ne slažem se, 5 - Uopće se ne slažem.

U analizi korelata redistributivnih preferencija korištene su sljedeće varijable iz istraživanja Eurobarometra: percipirane dohodovne nejednakosti, percepcija jednakosti šansi i percepcija meritokratskog načela da svatko dobije što zaslužuje. Osim toga, kao korelati odabrani su i sljedeći makrostatistički pokazatelji: BDP per capita, udio poreza i doprinosa u BDP-u, udio troškova socijalne zaštite u BDP-u, stope zaposlenosti i nezaposlenosti, Ginijev koeficijent, omjer medijana i prosjeka nacionalnog dohotka, stope teške materijalne deprivacije i prisutnost postsocijalističkog nasljeđa. Među makrostatističke pokazatelje nije uvrštena stopa relativnog siromaštva dobivena temeljem »službene« Eurostatove linije siromaštva (definirane kao 60\% medijana nacionalnog dohotka) stoga što je relativno siromaštvo više mjera nejednakosti nego stvarnih životnih uvjeta, pa je zato viso- ko korelirano s Ginijevim koeficijentom kao mjerom nejednakosti. S druge strane, stopa teške materijalne deprivacije uzeta je kao aproksimativna mjera apsolutnog siromaštva.

Stvarne dohodovne nejednakosti mjerene su preko Ginijeva koeficijenta, koji se u literaturi i istraživanjima najčešće koristi kao mjera ekonomskih nejednakosti. Ginijev koeficijent računa se na temelju cijele distribucije dohodaka, za razliku od percentilnih omjera koji se odnose u pravilu na krajeve distribucije. Percepcija dohodovnih nejednakosti mjerena je preko slaganja s tvrdnjom »Nejednakosti u našoj zemlji su prevelike«. Percepcija jednakosti šansi i percepcija meritokratskog načela mjerene se preko tvrdnji: »Imam jednake šanse za napredovanje u životu kao i svi drugi u društvu « te »Vjerujem da u našoj zemlji svatko dobije što zaslužuje«. Slaganje s ove tri tvrdnje procjenjivano je preko već prije navedene peterostupanjske Likertove ljestvice.

S obzirom na upitnik korišten $\mathrm{u}$ istraživanjima Eurobarometra, glavni mehanizmi redistributivne politike vezani su za četiri područja: porezni sustav, sustav socijalne zaštite (socijalna država), obrazovanje te politiku plaća/tržišta rada. Sklonost ispitanika prema pojedinim mehanizmima mjerena je preko 4 tvrdnje: 1. »Bogatiji građani trebaju plaćati veće poreze da bi vlada imala više sredstava za borbu protiv siromaštva« $(1$ - Potpuno se slaže, 2 - Uglavnom se slaže, 3 - Uglavnom se ne slaže, 4 - Uopće se ne slaže), 2. »Visoka razina izdataka za zdravstvenu skrb, obrazovanje i socijalnu zaštitu mora biti zajamčena, iako to može dovesti do porasta poreza « (ispitanici biraju ovu ili alternativnu tvrdnju »Porezi trebaju biti smanjeni, čak iako to znači nižu razinu zdravstvene skrbi, obrazovanja i socijalne zaštite «), 3. »Obrazovanje treba biti posve besplatno, iako to može značiti nižu razinu kvalitete « (ispitanici biraju ovu ili alternativnu tvrdnju »Školarine su nužne da bi se osigurala visoka kvaliteta obrazovanja, iako 
to znači da neki neće moći plaćati školarine «), 4. »Razumna minimalna plaća treba biti zajamčena svima, iako to može dovesti do manje radnih mjesta« (1 - Potpuno se slaže, 2 - Uglavnom se slaže, 3 - Uglavnom se ne slaže, 4 - Uopće se ne slaže). Prva tvrdnja odnosi se na porezni sustav, druga na sustav socijalne zaštite, treća na obrazovanje i četvrta se odnosi na politiku plaća.

Kako bi se istražili korelati redistributivnih preferencija, korištene su bivarijatne korelacijske analize i linearna regresija, dok je analiza preferencija građana prema mehanizmima redistribucije napravljena uz pomoć modela klaster analize u kojem je unaprijed definiran broj inicijalnih klastera (»k-means « metoda). Pošlo se od pretpostavke o postojanju 5 klastera koji odgovaraju modelima ili režimima socijalne politike u zemljama EU-a. Naime, polazeći od klasične tipologije režima socijalne države Es-
ping-Andersena (1990.), u razvijenim zapadnoeuropskim zemljama identificirana su tri modela/režima: anglosaksonski ili liberalni, skandinavski ili socijaldemokratski i kontinentalni ili konzervativni. Kako Esping-Andersenova tipologija nije obuhvatila zemlje srednje i južne Europe, ovim trima modelima najčešće se pridružuje još mediteranski ili južnoeuropski model (Ferrera, 1996.; Sapir, 2005.) te postsocijalistički model (Fenger, 2007.; Aidukaite, 2009., 2011.; Cerami i Stubbs, 2011.; Neesham i Tache, 2010.).

\section{REZULTATI}

\section{Razine dohodovnih nejednakosti, redistributivne preferencije $i$ korelati na makrorazini}

Opći je nalaz da su visoke redistributivne preferencije prisutne u gotovo svim zemljama EU-a (Slika 2.). Naime, u više od polo-

Slika 2.

Vlada treba poduzeti mjere da smanji razlike u dohotku* (2017.)

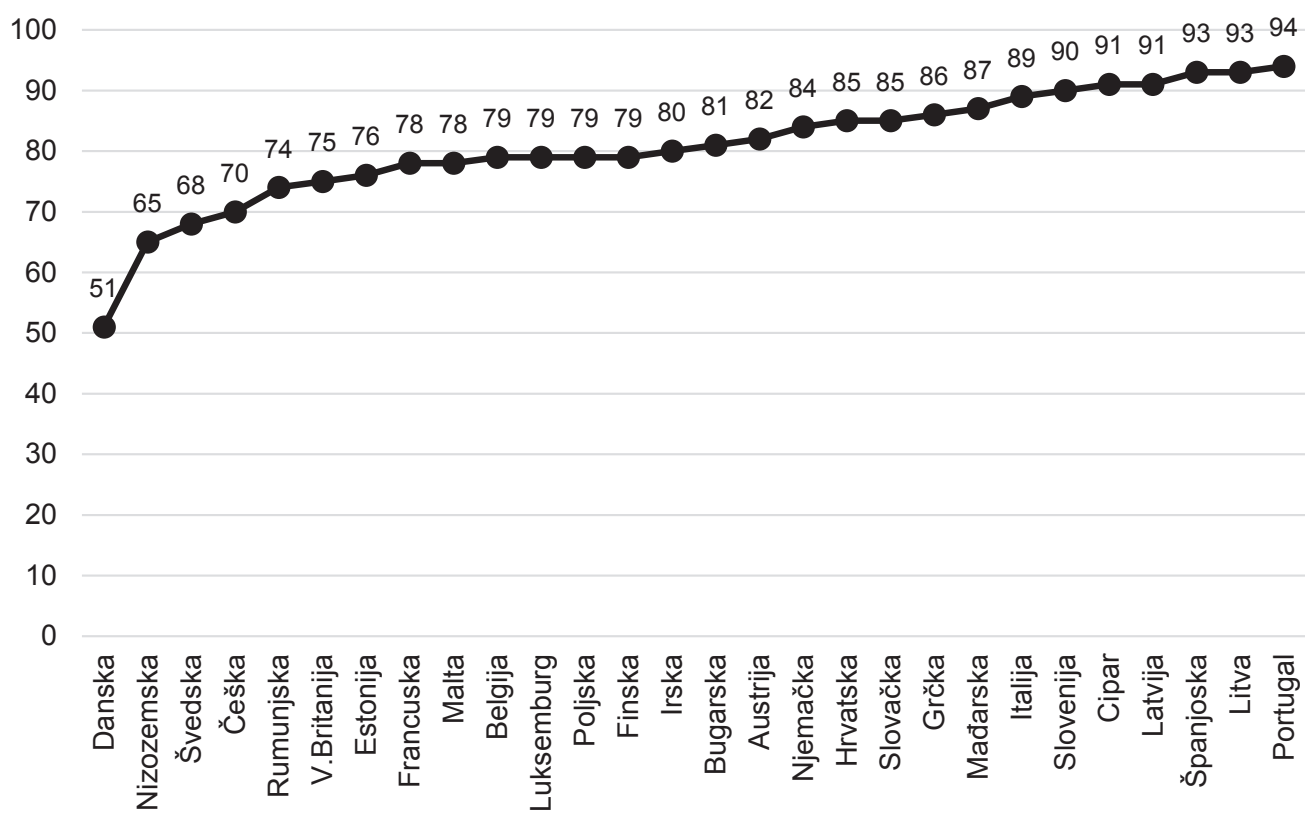

* Udio (\%) ispitanika koji se »potpuno slažu« ili »slažu« s tvrdnjom. Izvor: autorovi izračuni temeljem Eurobarometer (2018.). 
vine zemalja od $80 \%$ do $94 \%$ stanovništva podržava tvrdnju da vlada treba poduzeti mjere radi smanjenja dohodovnih razlika, dok je u preostalim zemljama spomenuti udio stanovništva između 51\% i 79\%. Ipak, evidentne su razlike među zemljama. Danska predstavlja slučaj za sebe jer je u ovoj zemlji udio stanovništva koji podržava intervenciju vlade tek za jedan postotni bod veći od polovine. Iza Danske, najniže redistributivne preferencije nalazimo u Nizozemskoj, Švedskoj i Češkoj, u kojima između 65\% i $70 \%$ građana smatra da vlada treba smanjiti razlike u dohotku. Na drugom kraju spektra su zemlje u kojima $90 \%$ ili više građana zagovara intervenciju vlade u dohodovnu distribuciju (Slovenija, Cipar, Latvija, Španjolska, Litva i Portugal). Hrvatska se nalazi u drugoj skupini zemalja s najvišim redis- tributivnim preferencijama. Zapravo, dvije skupine zemalja s najvišim redistributivnim preferencijama obuhvaćaju isključivo postsocijalističke ili južnoeuropske zemlje. Od postsocijalističkih zemalja, u donjoj polovici distribucije (niže preferencije) nalaze se jedino Češka, Rumunjska, Estonija i Poljska.

Pitanje je u kojoj mjeri redistributivne preferencije odražavaju stvarne dohodovne nejednakosti. Ako pođemo od Ginijeva koeficijenta kao pokazatelja dohodovnih nejednakosti, onda proizlazi da su redistributivne preferencije slabo povezane $s$ ekonomskim nejednakostima: koeficijent korelacije tek je nešto viši od 0,30 i nije statistički značajan (Slika 3.). S obzirom da se Ginijevi koeficijenti na Slici 3. odnose na 2017. godinu, važno je vidjeti što se događalo s dohodovnim nejednakostima u dužem

Slika 3.

Povezanost između redistributivnih preferencija i dohodovnih nejednakosti (Ginijevih koeficijenata) (2017.)

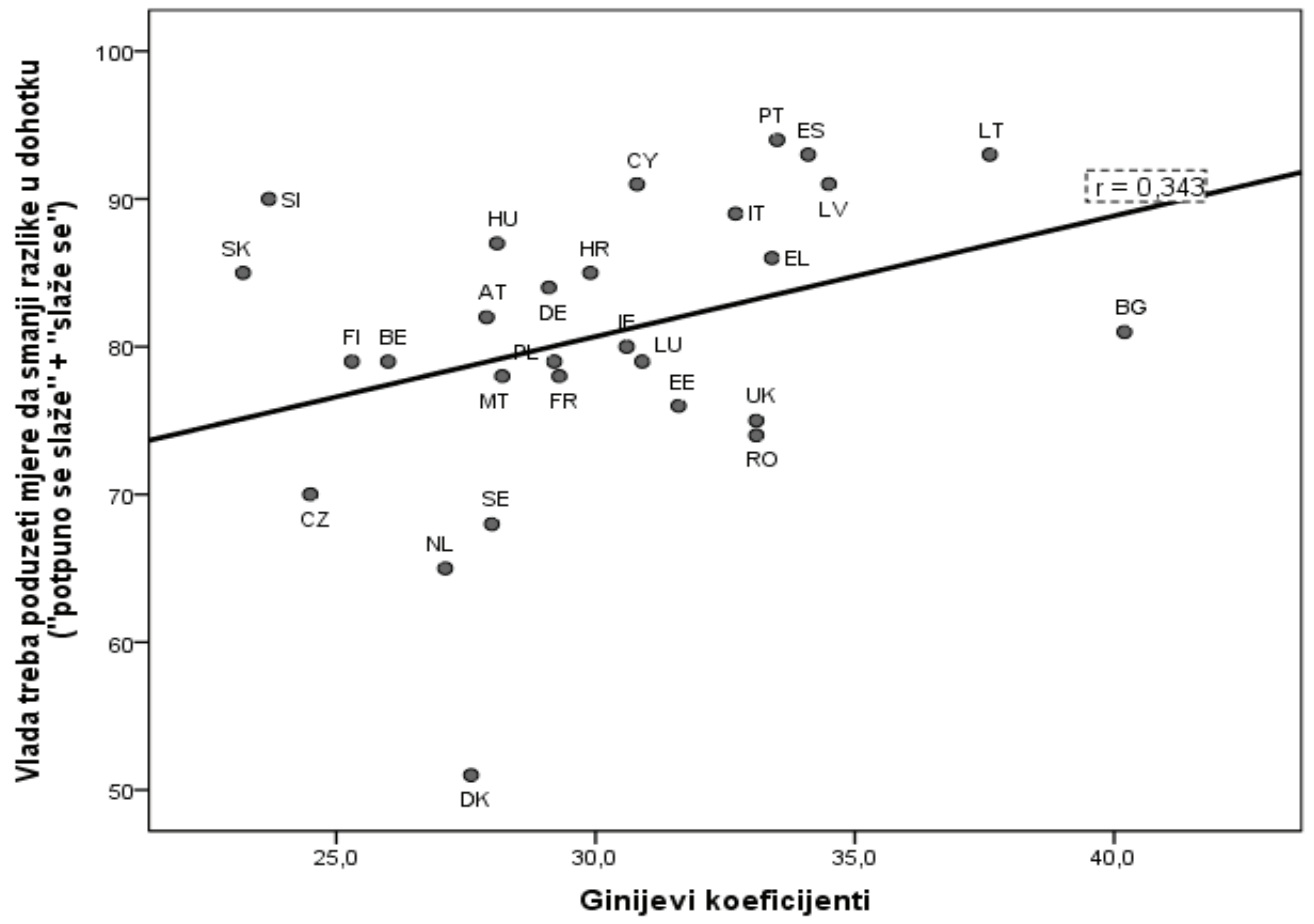

Izvor: autorovi izračuni temeljem Eurobarometer (2018.) i Eurostat. 
razdoblju jer su često potrebna desetljeća da se dogode znatnije promjene u ekonomskim nejednakostima. Kada se usporede dohodovne nejednakosti u 2017. godini s onima sredinom 1990-ih ili početkom 2000-ih (Slika 4.), primjetan je nešto veći rast nejednakosti (3-8 postotnih bodova) u skandinavskim zemljama (Danska, Švedska i Finska) koje inače imaju najniže ekonomke nejednakosti (i nakon spomenutog rasta nejednakosti, ove su zemlje ostale u skupini s najmanjim nejednakostima). S druge strane, zemlje s najvišim redistributivnim preferencijama zabilježile su blagi rast ili su zadržale visoke dohodovne nejednakosti u zadnjih dvadesetak godina (Grčka, Portugal, Španjolska, Litva, Latvija). Međutim, iako su Rumunjska i Bugarska zabilježile značajan rast dohodovnih nejednakosti u promatranom razdoblju (prva za četiri postotna boda, a druga čak za 15 postotnih bodova), obje su u donjoj polovini distribucije kada su u pitanju redistributivne preferencije (tek četiri zemlje imaju niže redistributivne preferencije od Rumunjske).

S obzirom da su stvarne nejednakosti slab prediktor redistributivnih preferencija, sljedeći je cilj bio analizirati vezu između percepcije nejednakosti i distributivnih preferencija. U 21 zemlji EU-a $80 \%$ i više građana smatra da su dohodovne nejednakosti prevelike (Slika 5.). Najmanji udio onih koji se slažu s tvrdnjom o prevelikim nejednakostima nalazimo u skandinavskim zemljama i Nizozemskoj (uglavnom ispod 70\%), a najveći (preko 90\%) opet u postsocijalističkim i južnoeuropskim zemljama, među kojima se još nalazi i Njemačka. Hrvatska se ponovno nalazi u drugoj skupini zemalja s najvišim udjelom građana koji smatraju da su nejednakosti u zemlji prevelike.

Slika 4

Ginijevi koeficijenti: 1995. i 2017.

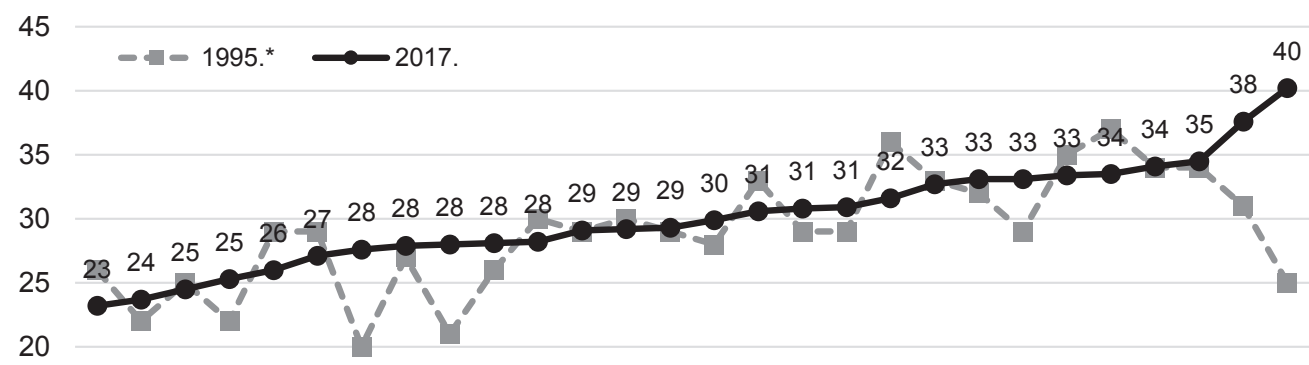

15

10

5

0

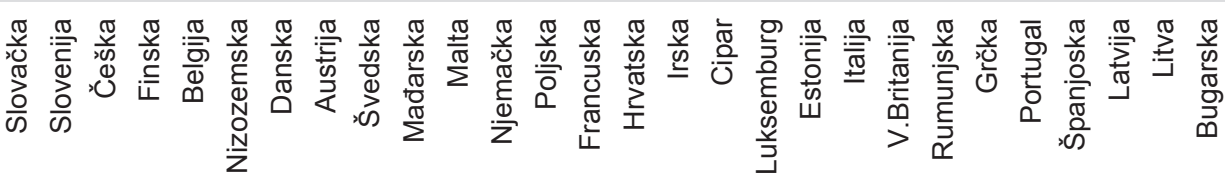

* Podaci za Bugarsku, Rumunjsku, Estoniju, Cipar, Latviju, Litvu, Mađarsku, Maltu, Poljsku i Sloveniju odnose se na 2000.; podaci za Češku i Hrvatsku odnose se na 2001., za Slovačku na 2005., za Finsku na 1996. te za Švedsku na 1997.

Izvor: Eurostat (Državni zavod za statistiku za RH u 2001.). 
Slika 5.

Dohodovne nejednakosti u mojoj zemlji su prevelike* (2010. i 2017.)

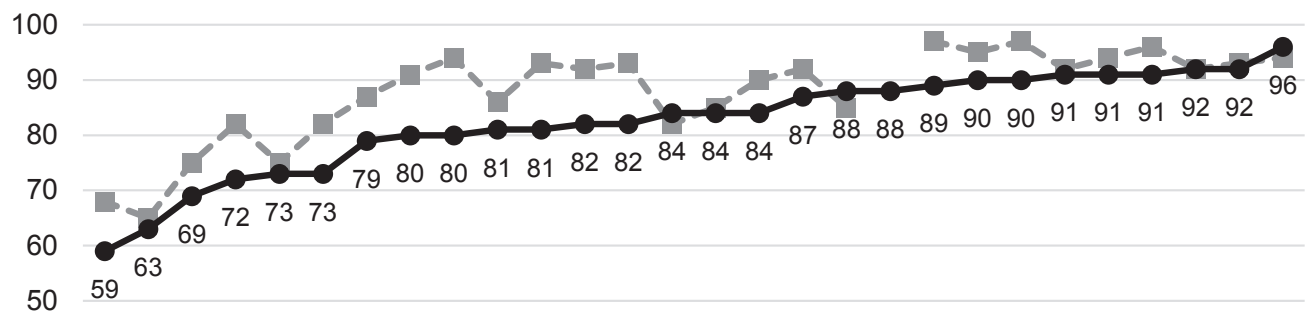

$40-2010 . \quad-2017$.

30

20

10

0

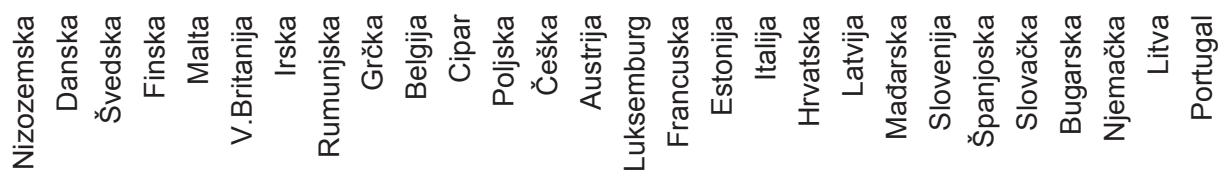

* Udio (\%) ispitanika koji se "potpuno slažu« ili "slažu« s tvrdnjom.

Nedostaje podatak za Hrvatsku u 2010. zato što tada nije bila članica EU-a.

Izvor: autorovi izračuni temeljem Eurobarometer (2010., 2018.).

Za razliku od pokazatelja stvarne nejednakosti, veza između redistributivnih preferencija i percepcije dohodovnih nejednakosti je vrlo snažna $(r=0,807)$ i pozitivna (Slika 6.). Osim toga, željelo se provjeriti preko linearnog regresijskog modela jesu li i neke druge varijable povezane s redistributivnim preferencijama (Tablica 1.). Kada se u regresijski model uvrste ključne makrostatističke varijable (vidi metodološko poglavlje), proizlazi da nijedna druga (osim percepcije dohodovnih nejednakosti) nije statistički značajno povezana sa zavisnom varijablom (redistributivnim preferencijama). 
Slika 6.

Povezanost između redistributivnih preferencija i percepcije dohodovnih nejednakosti (2017.)

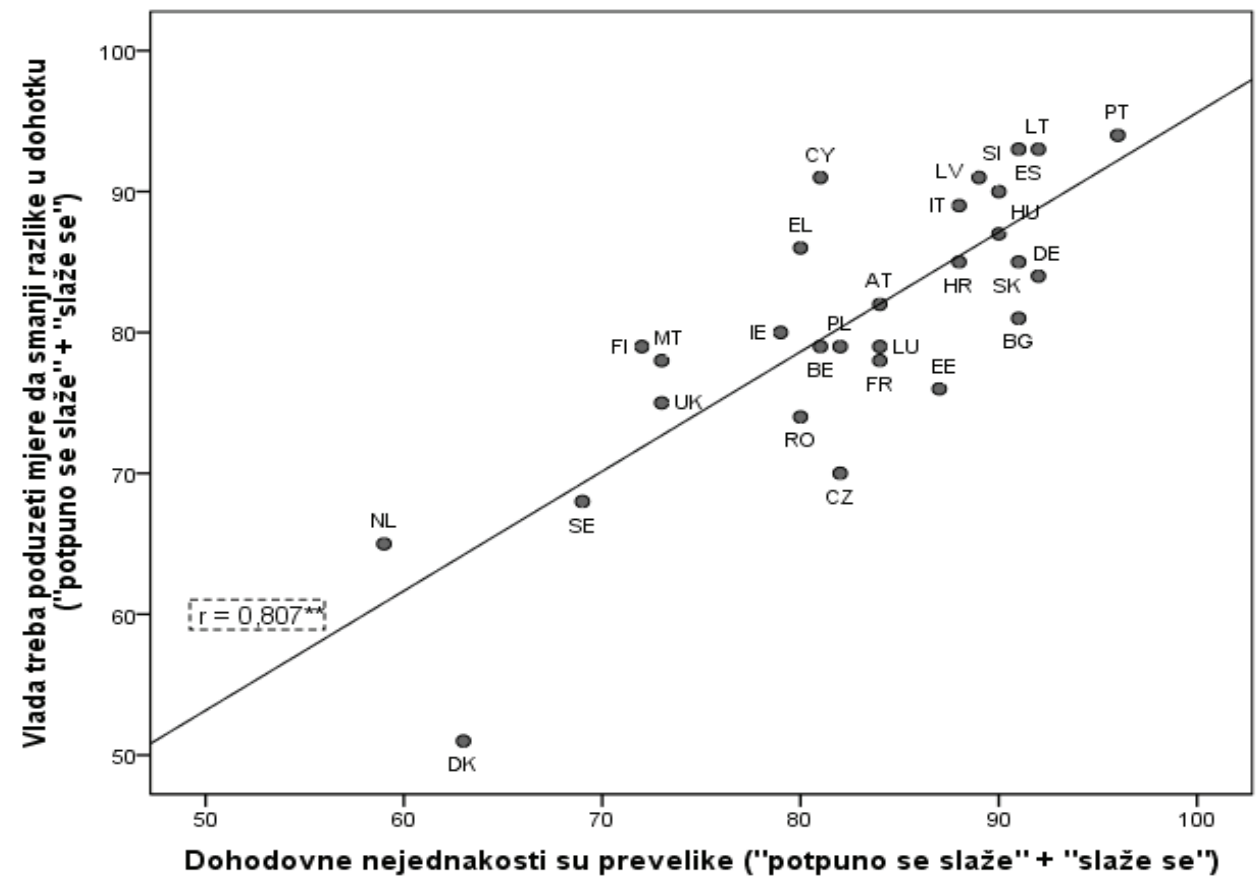

${ }^{* *} \mathrm{p} \leq 0,01$

Izvor: autorovi izračuni temeljem Eurobarometer (2018.).

Tablica 1.

Povezanost redistributivnih preferencija i odabranih (makro)pokazatelja (linearni regresijski model)

\begin{tabular}{lccc}
\hline & $\begin{array}{c}\text { Standardizirani } \\
\text { beta koeficijenti }\end{array}$ & $\mathrm{t}$ & $\mathrm{p}$ \\
\hline Nejednakosti su prevelike & 0,784 & 4,606 & $0,000^{\star *}$ \\
\hline Imam jednake šanse za napredovanje u društvu kao i svi drugi & $-0,254$ & $-1,035$ & 0,316 \\
\hline Stope nezaposlenosti & $-0,089$ & $-0,413$ & 0,685 \\
\hline Stope zaposlenosti & $-0,171$ & $-0,791$ & 0,441 \\
\hline BDP per capita (euro) & $-0,177$ & $-0,878$ & 0,393 \\
\hline Udio troškova socijalne zaštite u BDP-u & $-0,144$ & $-0,440$ & 0,666 \\
\hline Omjer medijana i prosjeka nacionalnog dohotka & $-0,048$ & $-0,203$ & 0,842 \\
\hline Ginijev koeficijent & 0,018 & 0,065 & 0,949 \\
\hline Udio poreza i doprinosa u BDP-u & $-0,053$ & $-0,181$ & 0,859 \\
\hline Stope teške materijalne deprivacije & $-0,201$ & $-0,798$ & 0,437 \\
\hline Socijalističko nasljeđe $\quad-0,473$ & $-1,982$ & 0,065 \\
\hline \multicolumn{1}{c}{$R^{2}=0,743 ; \quad$ Adjusted $R^{2}=0,592$} & & \\
\hline
\end{tabular}

Izvor: autorovi izračuni temeljem Eurobarometer (2018.) i Eurostat. 
Slika 7.

Povezanost između percepcije dohodovnih nejednakosti i ostvarenosti načela socijalne pravednosti (2017.)

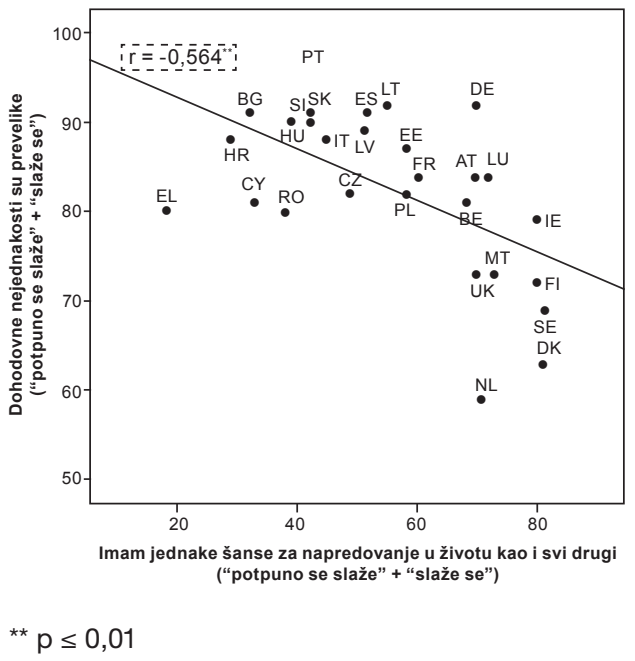

Izvor: autorovi izračuni temeljem Eurobarometer (2018.).

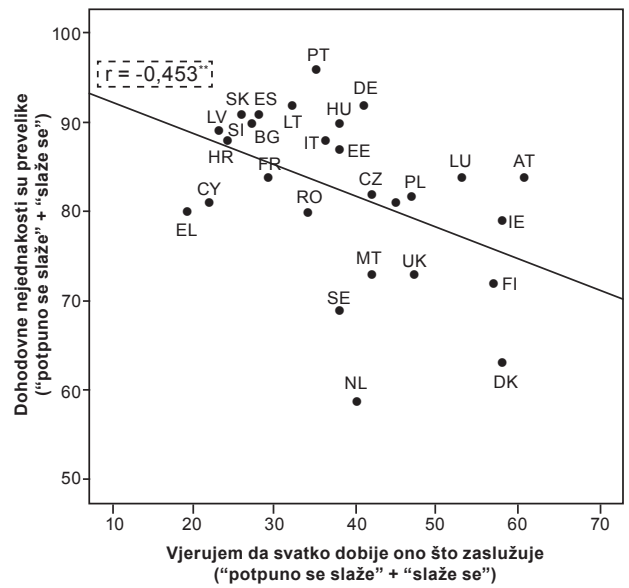

na dohodovnoj ljestvici. Unatoč visokim redistributivnim preferencijama, relativno mali postotak građana EU-a sebe svrstava u donje dohodovne decile (1-3 decil). U 16 zemalja ovaj je udio ispod $10 \%$, dok se u preostalim zemljama udjel kreće od $10 \%$ do $16 \%$, uz izuzetak Bugarske i Portugala u kojima iznosi 21\% (Slika 8.). Prema samopercepciji građana, zemlje EU-a predstavljaju dominantno srednjoklasna društva (udio srednjih decila kreće se uglavnom od $60 \%$ do $75 \%$ ). U Hrvatskoj se u srednje decile (4-6 decil) svrstalo gotovo $70 \%$ građana. Međutim, neke su zemlje, prema percepciji građana, većinski gornjoklasne (većinu čine građani u 7-10 decilu) ili bi to mogle uskoro postati. U odnosu na sve druge zemlje izdvaja se Nizozemska u kojoj preko 2/3 građana sebe smještava u gornja četiri decila. U skandinavskim zemljama i Luksemburgu udio građana koji sebe svrstavaju u gornje decile prelazi $40 \%$. 
Slika 8.

Percepcije vlastitog položaja na dohodovnoj ljestvici (2017.)

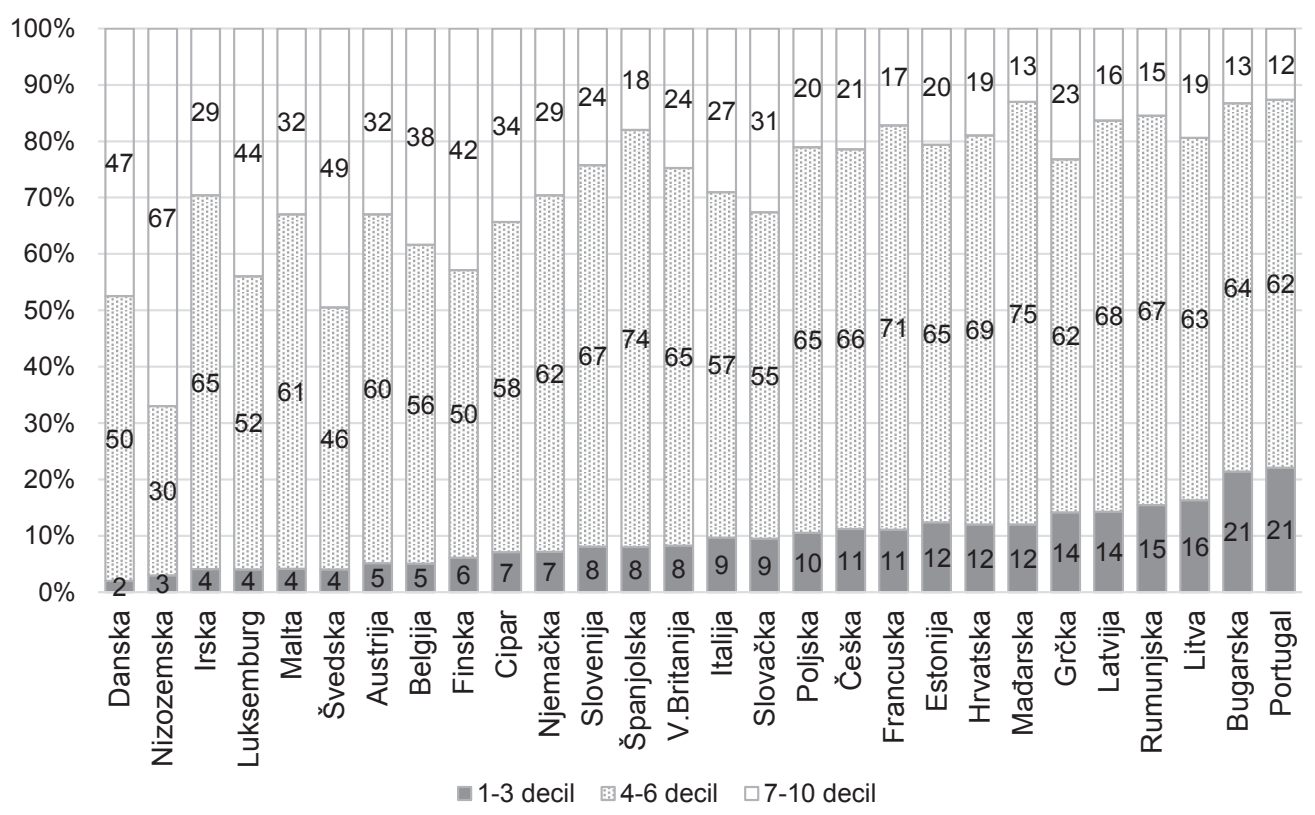

Izvor: autorovi izračuni temeljem Eurobarometer (2018.).

U većini zemalja percepcije o vlastitom mjestu na dohodovnoj ljestvici nisu u skladu s percepcijama modela ili oblika socijalne strukture. Ako pođemo od 5 tipova socijalne strukture (Slika 9.) koje razlikuje međunarodno istraživanje socijalnih nejednakosti (International Social Survey Project - ISSP) provedeno 2009. godine (Gesis, 2017.), među građanima ogromne većine zemalja EU-a prevladava mišljenje da u njihovim zemljama postoji oblik socijalne strukture u kojem je relativna većina građana na dnu dohodovne ljestvice (dohodovna struktura tipa A ili tipa B, Slika 10.). Hrvatska ulazi u skupinu zemalja u kojoj preko $85 \%$ građana smatra da je relativna većina ljudi na dnu dohodovne ljestvice (u ovoj su skupini još Latvija, Mađarska i Bugarska). S druge strane, u skandinavskim zemljama, Nizozemskoj i Belgiji između $35 \%$ i $40 \%$ ispitanika (relativna većina) smatra kako se najveći udio stanovništva u njihovim zemljama nalazi u sredini ili u gornjem dijelu dohodovne distribucije (dohodovna struktura tipa D ili tipa E, Slika 10.), s tim da se Danska izdvaja od svih drugih članica EU-a po tome što čak apsolutna većina ispitanika (63\%) smatra da je socijalna struktura u njihovom društvu nalik tipu D ili E. 
Slika 9.

Tipovi socijalne strukture prema ISSP (2009.)

\begin{tabular}{|c|c|c|c|c|}
\hline 吕 & & & & \\
\hline $\begin{array}{c}\text { Tip A } \\
\text { Mala elita na vrhu, } \\
\text { vrlo malo ljudi u } \\
\text { sredini i velika } \\
\text { masa ljudi na dnu }\end{array}$ & $\begin{array}{c}\text { Tip B } \\
\text { Društvo u obliku } \\
\text { piramide s malom } \\
\text { elitom na vrhu, } \\
\text { nešto više ljudi u } \\
\text { sredini i većinom } \\
\text { na dnu }\end{array}$ & $\begin{array}{c}\text { Tip C } \\
\text { Oblik piramide s } \\
\text { tim da je malo ljudi } \\
\text { na dnu }\end{array}$ & $\begin{array}{c}\text { Tip D } \\
\text { Društvo s većinom } \\
\text { ljudi u sredini }\end{array}$ & $\begin{array}{c}\text { Tip E } \\
\text { Većina ljudi je blizu } \\
\text { vrha, a vrlo je malo } \\
\text { blizu dna }\end{array}$ \\
\hline
\end{tabular}

Slika 10.

Kojem tipu socijalne strukture je najbliže društvo u kojem živite (2009.)

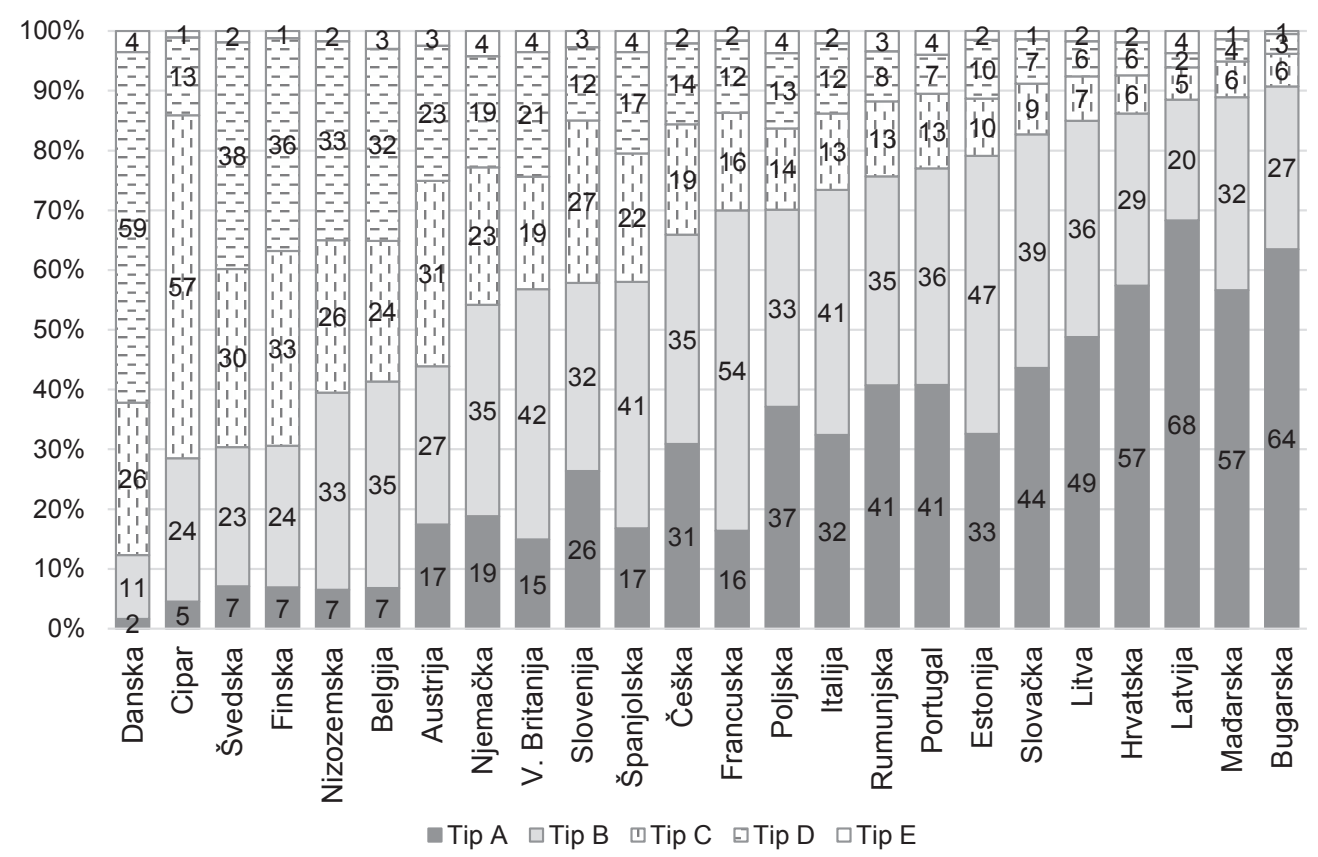

Napomena: ISSP nije obuhvatio sljedeće zemlje EU-a: Grčku, Maltu, Luksemburg i Irsku (podaci za Belgiju odnose se samo na Flandriju).

O tipovima socijalne strukture vidi Sliku 9.

Izvor: autorovi izračuni temeljem Gesis, 2017. 
Gimpelson i Treisman (2018.) procijenili su Ginijeve koeficijente za grafove koji predstavljaju 5 tipova socijalne strukture (Slika 9.) polazeći od pretpostavke da u grafovima svaki od 7 slojeva predstavlja dohodovni razred te da je ista distanca ili razlika između dohodovnih razreda. Prema njihovim procjenama, Ginijev koeficijent za socijalnu strukturu tipa A iznosi 0,42 , za tip B 0,35 , za tip C 0,30, za tip E 0,20 i za tip F 0,21 . Kada se usporede prosječni percipirani Ginijevi koeficijenti sa stvarnima u 2009. godini (Slika 11.), proizlazi da ispitanici u ogromnoj većini zemalja EU-a precjenjuju razinu nejednakosti. To se posebice odnosi na ispitanike iz postsocijalističkih zemalja. Procijenjeni Ginijevi koeficijenti u Češkoj, Sloveniji, Slovačkoj i Mađarskoj bili su od
9 do 13 postotnih bodova veći od stvarnih. Iza ove skupine zemalja slijede Hrvatska i Bugarska u kojima su procijenjeni Ginijevi koeficijenti za 6 postotnih bodova bili veći od stvarnih. U zemljama koje nemaju socijalističkog nasljeđa razlika između procijenjenih i stvarnih Ginijevih koeficijenata ne prelazi 3 postotna boda, s tim da ispitanici u Danskoj, Španjolskoj i Velikoj Britaniji podcjenjuju stvarnu razinu nejednakosti (mjerenu preko Ginijeva koeficijenta).

Za razliku od modela socijalne strukture u kojem postoji mala elita na vrhu i ogromna većina stanovništava na dnu ljestvice, za kojega ispitanici smatraju da postoji u većini zemalja EU-a, u svim zemljama ispitanici smatraju poželjnim onaj oblik socijalne strukture u kojem je većina stanovništva u

Slika 11.

Razlika između percipiranog* i stvarnog Ginijevog koeficijenta (u postotnim bodovima, 2009.)

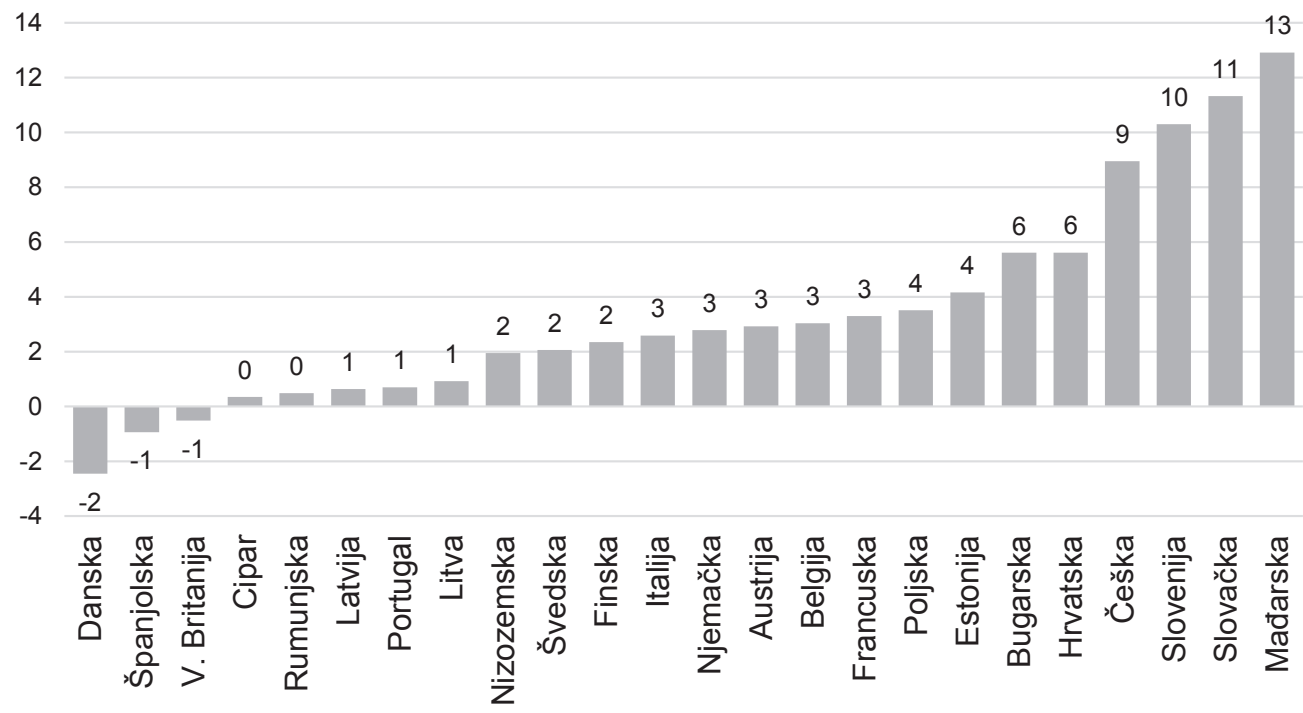

* Percipirani Ginijev koeficijent određen je na način da je svakom tipu socijalne strukture pridružen Ginijev koeficijent koji su izračunali Gimpelson iTreisman (2018.) (Tip $A=0,42$; Tip B $=0,35$, Tip C $=0,30$; Tip $E=0,20$ $\mathrm{iTip} F=0,21$ ), a zatim je za svaku zemlju izračunat ponderirani prosječni Ginijev koeficijent (ponderiran prema udjelima ispitanika koji su odabrali tip socijalne strukture za koji su smatrali da odgovara njihovoj zemlji).

Napomena: ISSP nije obuhvatio sljedeće zemlje EU-a: Grčku, Maltu, Luksemburg i Irsku (podaci za Belgiju odnose se samo na Flandriju).

Izvor: autorovi izračuni prema podacima ISSP (Gesis, 2017.) i Eurostata. 
sredini ili u gornjem dijelu dohodovne distribucije (dohodovna struktura tipa D ili tipa $\mathrm{E}$, Slika 12.). Udio ispitanika po zemljama koji preferiraju ove tipove dohodovne strukture kreće se od 63\% u Češkoj i Slovačkoj do $91 \%$ u Latviji (87\% u Hrvatskoj). Tipove socijalne strukture s izraženim nejednakostima između vrha i dna ljestvice i relativnom većinom na dnu ljestvice (tip A ili B) preferira u pravilu manje od $10 \%$ stanovništva u zemljama EU-a. Tip socijalne strukture koji sliči piramidi sa suženom bazom, odnosno s malim udjelom stanovništva na dnu ljestvice (tip C) priželjkuje gotovo $30 \%$ ispitanika u Češkoj i Slovačkoj, ali manje od 10\% u Finskoj, Švedskoj ili Latviji.

\section{Mehanizmi dohodovne redistribucije}

Različiti se kanali i mehanizmi mogu koristiti u cilju smanjenja dohodovnih razlika i nejednakosti. Četiri su mehanizma analizirana: porezni sustav, obrazovanje, socijalna zaštita i politike plaća i tržišta rada. U sva četiri područja nezaobilazna je uloga države. Kako bi se istražila naklonost građana u zemljama EU-a prema određenim mehanizmima redistribucije ili njihovoj kombinaciji, napravljena je klaster analiza na način da je zadan inicijalni broj klastera (5), što je objašnjeno u metodološkom dijelu rada. Prije klaster analize varijable su

Slika 12.

Koji tip socijalne strukture preferirate (2009.)

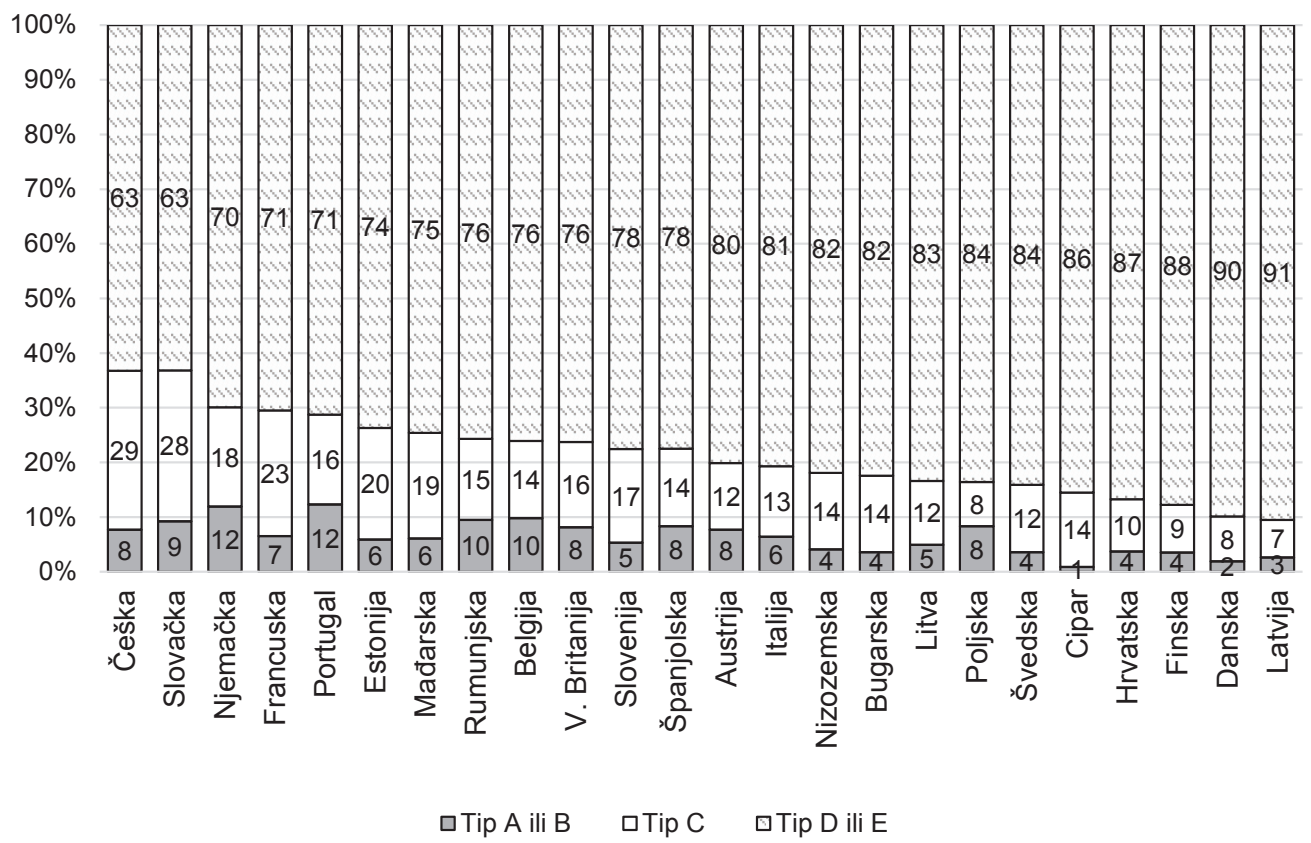

Napomena: ISSP nije obuhvatio sljedeće zemlje EU-a: Grčku, Maltu, Luksemburg i Irsku (podaci za Belgiju odnose se samo na Flandriju).

O tipovima socijalne strukture vidi Sliku 9.

Izvor: autorovi izračuni prema podacima ISSP (Gesis, 2017.). 
standardizirane na način da su pretvorene u Z-vrijednosti. Prvo je provjerena značajnost modela s 5 klastera preko ANOVE i ustanovljeno da su sve četiri dimenzije ili varijable statistički značajne (Tablica 2.). i jamčenje minimalne plaće, a blago pozitivno koreliran s besplatnim obrazovanjem i visokim izdacima za socijalnu zaštitu, pa ispitanici u ovom klasteru više važnosti pridaju osiguranju besplatnog obrazovanja

Tablica 2.

Rezultati ANOVE za 5 klastera

\begin{tabular}{lcccccc}
\hline Varijable & $\begin{array}{c}\text { Mean } \\
\text { Square }\end{array}$ & df & $\begin{array}{c}\text { Mean square } \\
\text { error }\end{array}$ & df & $\mathrm{F}$ & $\mathrm{p}$ \\
\hline Visoki porezi za bogate & 4,468 & 4 & 0,369 & 22 & 12,096 & 0,000 \\
\hline Besplatno obrazovanje & 4,503 & 4 & 0,363 & 22 & 12,402 & 0,000 \\
\hline Visoki troškovi za socijalnu zaštitu & 3,844 & 4 & 0,483 & 22 & 7,960 & 0,000 \\
\hline Zajamčena razumna minimalna plaća & 2,601 & 4 & 0,709 & 22 & 3,670 & 0,020 \\
\hline
\end{tabular}

Nisu uključeni podaci za Hrvatsku jer nije bila članica EU-a.

Izvor: autorovi izračuni temeljem Eurobarometer (2010.).

Prvo, dobiveni klasteri (Tablica 3.) ne odgovaraju režimima socijalne politike za koje se obično smatra da postoje u zemljama EU-a. Jedino su sve skandinavske zemlje ostale $u$ jedinstvenom klasteru, u koji su još svrstane Slovačka i Velika Britanija. Prvi klaster čine tri kontinentalne zemlje, dvije južnoeuropske i jedna postsocijalistička. Ovaj je klaster blago negativno koreliran s varijablama visoki porezi za bogate i visoki izdaci za socijalnu zaštitu te snažnije negativno koreliran s dimenzijom besplatnog obrazovanje (Slika 13.). Gotovo ni u jednoj zemlji ove skupine besplatno obrazovanje nema potporu apsolutne većine građana. $\mathrm{S}$ obzirom na blagu pozitivnu povezanost $\mathrm{s}$ varijablom zajamčene minimalne plaće, ovaj klaster čine zemlje čiji građani najviše preferiraju redistribuciju kroz mehanizam minimalne plaće, uz veliku zadršku prema besplatnom obrazovanju. Drugi klaster, koji čine Francuska i Luksemburg te dvije postsocijalističke zemlje, negativno je koreliran s varijablama visoki porezi za bogate i izdašnoj socijalnoj zaštiti. Treći klaster uglavnom čine postsocijalističke zemlje ili zemlje u kojima dio stanovništva ima iskustvo življenja u socijalizmu (Njemačka). Oni dominantno podržavaju redistribuciju $\mathrm{kroz}$ besplatno obrazovanje i više poreze za bogate. Četvrti klaster čine južnoeuropske i postsocijalističke zemlje u kojima ispitanici podržavaju besplatno obrazovanje i visoke izdatke za socijalnu zaštitu, ali ispitanici u ovom klasteru najviše naglašavaju mehanizam većih poreza za bogatije. U petom klasteru dominiraju skandinavske zemlje, pa nije iznenađujuće da ovaj klaster ima najviše klasterske sredine na trima dimenzija: besplatno obrazovanje, visoki izdaci za socijalnu zaštitu i zajamčena razumna minimalna plaća. Jedino je negativna korelacija s varijablom većih poreza za bogate s obzirom da skandinavske zemlje već imaju visoke i progresivne poreze. Velika Britanija također ima tradiciju poreznog financiranja sustava socijalne sigurnosti (npr. sustav zdravstvene zaštite). 
Tablica 3.

Raspored zemalja po klasterima

\begin{tabular}{ccccc}
\hline 1. klaster & 2. klaster & 3. klaster & 4. klaster & 5. klaster \\
\hline Austrija $(1,209)$ & Estonija $(1,093)$ & Irska $(1,089)$ & Bugarska $(1,115)$ & Danska $(1,235)$ \\
\hline Belgija $(0,739)$ & Francuska $(0,787)$ & Latvija $(0,703)$ & Cipar $(1,235)$ & Finska $(1,064)$ \\
\hline Češka $(0,859)$ & Luksemburg $(0,874)$ & Litva $(1,179)$ & Grčka $(1,224)$ & Slovačka $(1,373)$ \\
\hline Italija $(1,405)$ & Poljska $(1,161)$ & Malta $(0,999)$ & Mađarska $(0,685)$ & Švedska $(1,509)$ \\
\hline Nizozemska $(2,179)$ & & Njemačka $(2,238)$ & Španjolska $(1,172)$ & V. Britanija $(0,754)$ \\
\hline Portugal $(1,628)$ & Rumunjska $(1,044)$ & \\
\hline \multicolumn{5}{c}{ Slovenija $(1,618)$} \\
\hline
\end{tabular}

Napomena: U zagradama je podatak o udaljenosti zemlje od pripadajućeg klastera.

Nema podataka za Hrvatsku jer nije bila članica EU-a.

Izvor: autorovi izračuni temeljem Eurobarometer (2010.).

Slika 13.

Klasterske sredine prema područjima redistribucije

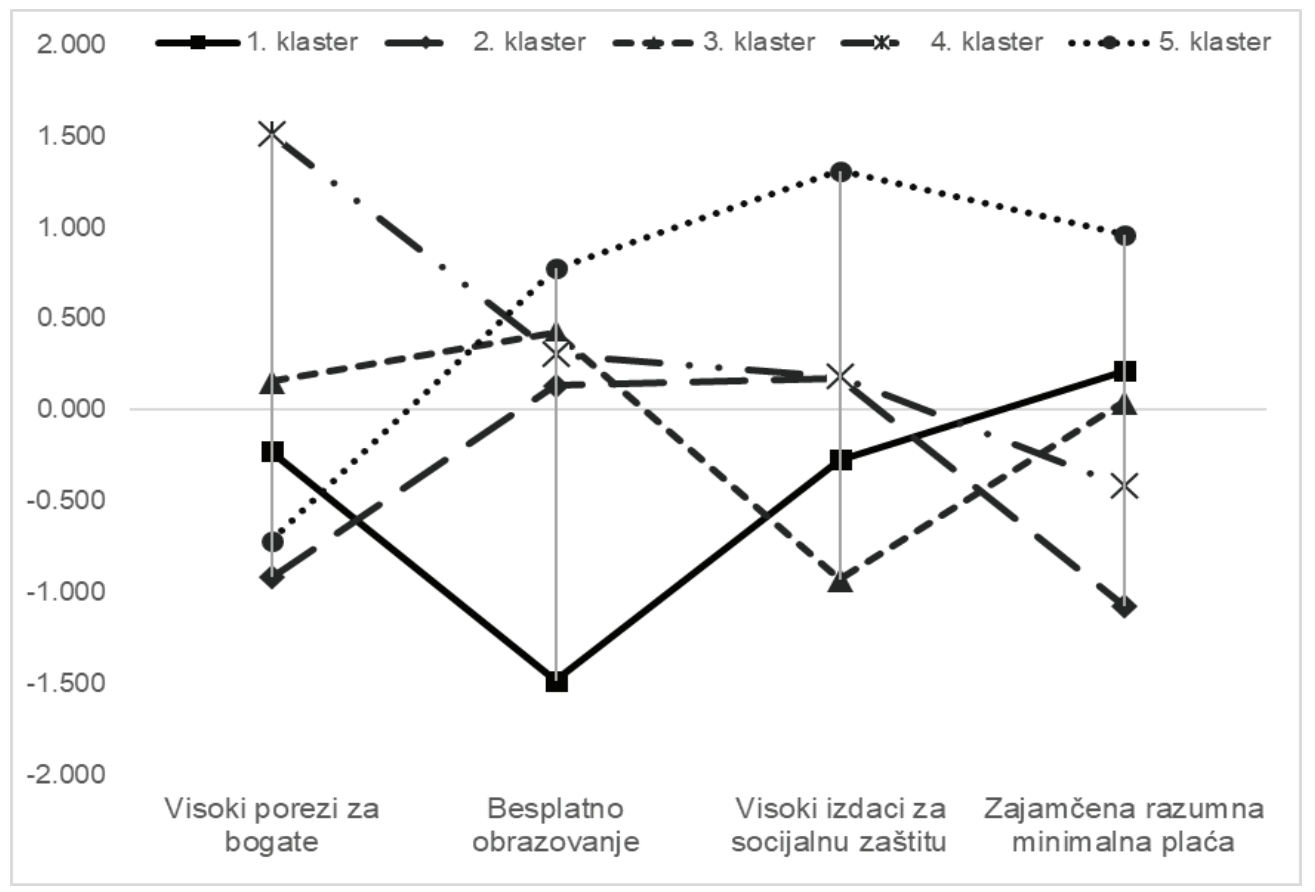

Nisu uključeni podaci za Hrvatsku jer nije bila članica EU-a.

Izvor: autorovi izračuni temeljem Eurobarometer (2010.). 


\section{RASPRAVA}

Redistributivne preferencije slabo ovise o kretanju stvarnih dohodovnih nejednakosti. U zemljama EU-a ove su preferencije ostale visoke iako je dugoročno (tijekom prve polovice i prvih desetljeća druge polovice 20. stoljeća) došlo do smanjenja nejednakosti u dohotku i bogatstvu. Piketty i Saez (2014.) pokazali su da su dohodovne nejednakosti i nejednakosti u bogatstvu u Europi značajno pale u prvoj polovini 20. stoljeća, ali su ponovno porasle od 1980-ih. Na primjer, $10 \%$ najbogatijih su 1910. u Europi raspolagali s preko $45 \%$ nacionalnog dohotka, a 1980. godine s $30 \%$ nacionalnog dohotka, da bi taj udio narastao 2010. na $35 \% .{ }^{3}$ No, koncentracija bogatstva uvijek je veća nego koncentracija dohotka. U zadnjih 150 godina u Europi i SAD-u udio dohotka $10 \%$ superbogatih iznosio je između $30 \%$ i $50 \%$ nacionalnog dohotka, ali između $60 \%$ i $90 \%$ nacionalnog bogatstva. Analizirajući omjer između udjela bogatstva i udjela dohotka 10\% najbogatijih, Piketty i Saez (2014.) zaključuju da u Europi nejednakosti rastu u zadnjih nekoliko desetljeća zbog rasta udjela kapitalne imovine, a ne udjela najviših dohodaka. Kako prema Medgyesiju (2013.) tek rast nejednakosti veći od 10 postotnih bodova Ginijeva koeficijenta počinje utjecati na razinu redistributivnih preferencija, takav je utjecaj izostao jer je rast dohodovnih nejednakosti u sadašnjim članicama EU-a, temeljem analize kretanja Ginijevih koeficijenata, bio uglavnom manji od 5 postotnih bodova u posljednja dva do tri desetljeća, osim u Danskoj i Švedskoj (7-8 postotnih bodova) i Bugarskoj (15 postotnih bodova). Dostupni podaci za Hrvatsku također su potvrdili da su od polovine 1970-ih do danas primjetne tek male varijacije Ginijeva koeficijenta u rasponu od 4 postotna boda. Prema tome, rast dohodovnih nejednakosti ne može biti ključni čimbenik visoke razine redistributivnih preferencija, već je to percepcija dohodovnih nejednakosti i osjetljivost građana zemalja EU-a na ekonomske nejednakosti. Očito da se percepcija visoke razine nejednakosti povezuje s narušavanjem ključnih društvenih vrednota ili načela, kao što su načela socijalne pravde i zasluga. Kada postoji izražena nejednakost plaća ili dohodaka, dovodi se u pitanje legitimitet tržišnih ishoda i meritokratsko načelo zasluga (Kuhn, 2016.). Izgleda da je, na primjer, javnost u Hrvatskoj osjetljiva na bilo kakve nejednakosti, pa i one umjerene jer ih percipira kao nelegitimne ili čak kao nelegalne. Sadašnje nejednakosti promatraju se kao posljedica procesa pretvorbe i privatizacije iz 1990-ih, a koji su percipirani od većine građana kao nepravedni i koruptivni.

Ipak, ranije spomenuta konstatacija da rast dohodovnih nejednakosti nije ključni čimbenik visoke razine redistributivnih preferencija, već je to percepcija dohodovnih nejednakosti i osjetljivost građana zemalja EU-a na ekonomske nejednakosti, odnosi se samo na nejednakosti u dohotku, ali ne i na nejednakosti u bogatstvu. Ispitanici često ne prave razliku između distribucije dohotka i distribucije bogatstva. Iako se u pitanjima može tražiti izjašnjavanje građana o razini dohodovnih nejednakosti, nije uvijek jasno jesu li ispitanici u svojim odgovorima mislili upravo na nejednakosti u dohotku ili na nejednakosti u bogatstvu. To je važno imati na umu jer su nejednakosti u bogatstvu u svim zemljama veće nego nejednakosti u dohotku. Osim toga, raspoloživi podaci ukazuju da razlike u bogatstvu i dalje rastu kako u europskim tako i u drugim razvijenim zemljama (Piketty,

\footnotetext{
${ }^{3}$ Oni pokazuju da je udio ukupnog dohotka $10 \%$ najbogatijih u SAD-u pao s $45 \%$ u 1930. na $33 \%$ u 1970 ., da bi u 2010. dosegnuo 48\% (Piketty i Saez, 2014.).
} 
2014. ${ }^{4}$. Dok su nejednakosti u bogatstvu u europskim zemljama značajno smanjene od kraja 19. do sredine druge polovine 20. stoljeća, one brže ili sporije rastu u većini zemalja u razdoblju od 1970. do 2010. Na primjer, $1 \%$ najbogatijih je u Europi raspolagao s oko 20\% ukupnog bogatstva u 1970 . i s oko $25 \%$ u 2010 . U istom je razdoblju narastao udio bogatstva $10 \%$ najbogatijih sa $60 \%$ na oko $63 \%$ (Piketty, 2014.). ${ }^{5}$ Kako nam nisu bili dostupni podaci o nejednakostima u bogatstvu za zemlje EU-a, jer je takve informacije znatno teže prikupiti, moguće je da su ove rastuće nejednakosti u bogatstvu utjecale i na visoke redistributivne preferencije građana zemalja EU-a.

Stanovnici u zemljama EU-a često pogrešno percipiraju razinu nejednakosti u društvu i svoje mjesto na dohodovnoj ljestvici. U ovom pogledu postoje značajne razlike između postsocijalističkih zemalja i zemalja bez iskustva življenja u socijalizmu. Na primjer, ustanovljena je statistički značajna razlika među spomenutim skupinama zemalja u pogledu udjela ispitanika koji smatraju da su nejednakosti u njihovim zemljama prevelike $(\mathrm{t}=-2,503, \mathrm{p} \leq 0,019)$. Međutim, nije pronađena statistički značajna razlika među ovim zemljama u pogledu redistributivnih preferencija (korelacija socijalističkog nasljeđa s redistributivnim preferencijama u regresijskom modelu bila je malo iznad granice značajnosti $(p \leq 0,069)$. Podaci potvrđuju da građani postsocijalističkih zemalja imaju veću »averziju« prema dohodovnim nejednakostima, ali da ne postoji jednoobrazni utjecaj socijalističkog nasljeđa na sve zemlje (Murthi i Tiongson, 2008.; Medgyesi, 2013.). Na primjer, post- socijalističke zemlje srednje i jugoistočne Europe iskazuju veće egalitarne preferencije nego zemlje bivšeg Sovjetskog Saveza (Murthi i Tiongson, 2008.). Osim toga, stavovi građana prema nejednakostima u postsocijalističkim zemljama evoluiraju i približavaju se stavovima građana u zapadnim zemljama bez socijalističkog nasljeđa, ali je ostalo karakteristično za građane u svim postsocijalističkim zemljama da žele veću ulogu države u redistribuciji i društvenom životu (Murthi i Tiongson, 2008.).

Nesavršene informacije o nejednakostima utječu na uvjerenja i distributivne preferencije. Bolja informiranost i veća svijest o dohodovnim nejednakostima u pravilu potiču zahtjeve za redistribucijom. Prema istraživanju Zilinskog (2014.), dostupnost točnih informacija o tome koliko zarađuje $0,1 \%$ najbogatijih u SAD-u utjecalo je na rast potpore od 6 postotnih bodova općoj i nespecificiranoj intervenciji vlade protiv nejednakosti. Međutim, točna informiranost o nejednakostima ne znači da će građani biti spremni podržati konkretne mjere vlade za redukciju nejednakosti, kao što su, na primjer, veći porezi. Zilinski tvrdi da Amerikanci žele manje nejednakosti, ali ne žele koristiti redistribuciju kao sredstvo za njihovu promjenu jer smatraju da vlada ne može ekonomski rast i razvoj učiniti pravednijim.

Građani EU-a načelno podržavaju sva četiri mehanizma redistribucije (porezi, obrazovanje, socijalna zaštita i minimalna plaća), ali im pridaju različitu važnost. Najveću potporu, uz najmanje varijacija, građani EU-a daju poreznom sustavu i progresivnom oporezivanju bogatijih. Kao što naglašavaju Simurina i sur. (2017.), iako je

\footnotetext{
${ }^{4} \mathrm{Npr}$., za Hrvatsku to ilustriraju podaci o štednji hrvatskih građana. Prema podacima Hrvatske narodne banke, u listopadu 2020. hrvatski su građani raspolagali ukupnim štednim depozitima u vrijednosti od oko 220 milijardi kuna. Međutim, postoji visoka koncentracija štednje u domaćim bankama jer 1,7\% štediša raspolaže s 43\% ukupne domaće štednje (Slobodna Dalmacija, 6. listopada 2020.; dostupno na: https://slobodnadalmacija. hr/vijesti/hrvatska/podaci-narodne-banke-vise-od-50-tisuca-hrvata-ima-stednju-vecu-od-milijun-kuna-u-bankama-gotovo-220-milijardi-1048977).

${ }^{5}$ U SAD-u je udio bogatstva $1 \%$ najbogatijih porastao od 1970 . do 210 . s $30 \%$ na oko $33 \%$, a udio bogatstva $10 \%$ najbogatijih sa $65 \%$ na preko $70 \%$ (Piketty, 2014.).
} 
primarni cilj svake porezne politike fiskalni, kroz porezni sustav mogu se ostvarivati razni nefiskalni ciljevi. Porezna politika direktno utječe na dohodovne nejednakosti, ali i indirektno kroz činjenicu da se porezima u svim zemljama financira veći ili manji dio naknada i usluga socijalne zaštite (Atkinson i sur., 2017.). Prije svega, utjecaj poreznog sustava na ekonomske nejednakosti ovisi o vrsti poreza i stupnju porezne progresivnosti. Poznato je, na primjer, da porezi na potrošnju imaju regresivni učinak jer siromašniji građani najveći dio svog dohotka usmjeravaju na potrošnju. S druge strane, znatno veći utjecaj na smanjenje nejednakosti ima progresivni sustav poreza na dohodak ili snižavanje stope poreza na potrošnju za dobra i usluge koje koriste uglavnom građani s nižim primanjima. Šimurina i sur. (2017.) dokazuju na primjeru zemalja EU-a da povećanje udjela poreza na rad za $1 \%$ u BDP-u rezultira smanjenjem dohodovnih nejednakosti za $0,33 \%$, a postotno povećanje udjela socijalnih doprinosa u BDP-u smanjuje nejednakosti za 0,39\% (učinci poreza na kapital i potrošnju na ekonomke nejednakosti nisu se pokazali statistički značajnima). U razdobljima kriza ili recesija za očekivati je da će dominirati primarna funkcija poreznog sustava: prikupljanje prihoda radi pokrića rashoda.

Ostala tri mehanizma redistribucije imaju nešto manju, ali i dalje većinsku podršku građana, s tim da je najmanja potpora besplatnom obrazovanju. Minimalna plaća sve se više prihvaća kao sredstvo borbe protiv siromaštva, ali i kao oblik regulacije tržišta rada kojim se ispravljaju tržišne nepravilnosti (Nestić i Blažević Burić, 2018.). Njome se ispravljaju potencijalno negativne posljedice nejednake pregovaračke moći radnika i poslodavaca, koja može dovesti do preniskih i nepravednih zarada u odnosu na graničnu proizvodnost radnika. Time minimalna plaća implicira načelo pravednih zasluga i smanjuje dohodovne nejednakosti u društvu (Wolscho,
2005.), iako njen učinak na dohodovne nejednakosti može biti prilično skroman ako je preniska ili ako znatan udio sredstava minimalne plaće odlazi pojedincima koji su u gornjim dohodovnim razredima distribucije (Horrigan i Mincy, 1994.; Müller, 2013.; Atkinson i sur., 2017.; Teal, 2019.). Kako ističe Johannessen (2019.): minimalna plaća ima i »minimalan učinak«. Sigurno da na dohodovne nejednakosti veći utjecaj ima općenito politika plaća u nekoj zemlji, a ne samo minimalna plaća. Na nejednakost plaća u nekoj zemlji utječe više faktora, ali ovdje bi bilo važno istražiti ulogu kolektivnog pregovaranja i socijalnog partnerstva.

Neki autori, poput Alta i Iversena (2017.) podržavaju redistributivne preferencije koje su usmjerene na sustav socijalne zaštite ili preciznije na socijalno osiguranje. U modelu socijalnog osiguranja potražnja za socijalnim naknadama povezana je s izloženošću rizicima (koja ovisi o obrazovanju, zanimanju, privrednom sektoru i sl.). Od programa socijalne zaštite koristi najviše imaju oni koji su bez dohotka, pa su preferencije za socijalnim naknadama povezane s redistributivnim preferencijama. Postoji negativna veza između visine dohotka i izloženosti rizicima. Na ovu vezu utječe i segmentacija tržišta rada (koncentracija rizika među nekvalificiranom i slabo plaćenom radnom snagom), ali i deindustrijalizacija (segregacija dijela radne snage u sektorima s nesigurnim i privremenim poslovima ili s nepunim radnim vremenom). Alt i Iversen (2017.) ističu da je među ovom radnom snagom sve više imigrantskih radnika, od čega ima koristi domaća kvalificirana radna snaga koja kupuje bazične usluge po nižim cijenama. Očito da nije ista potpora svim dijelovima sustava socijalne zaštite u različitim zemljama. Često je manja potpora onim sustavima koji nisu bazirani na načelu reciprociteta (socijalna pomoć ili neke mjere obiteljske politike) ili ako se vjeruje da su u takvim sustavima raširene zlouporabe prava. 
Izgleda da je najviše dilema vezano za potpuno besplatno obrazovanje, iako ga u zemljama EU-a podržava apsolutna većina građana. Jedine dvije zemlje u kojima relativna većina građana podržava plaćanje školarina, a ne posve besplatno školovanje, bile su Nizozemska i Austrija (u ovim zemljama besplatno školovanje podržava tek nešto više od trećine građana). Obrazovanje se percipira kao »veliki ujednačavač«, prije, svega, time što svim građanima otvara šanse za napredovanje u društvu (Walker i sur., 2019.). Poznato je da je obrazovanje nezaobilazni instrument u borbi protiv siromaštva, ali sve je više dokaza da obrazovanje prevenira ekstremne nejednakosti (Dabla-Norris i sur., 2015.; Coady i Dizioli, 2017.). OECD (2011.) vidi u obrazovanju glavno sredstvo za sprječavanje rasta dohodovnih nejednakosti kako u razvijenim tako i u nerazvijenim zemljama. The World Inequality Report 2018 (Alverado i sur., 2017.) zagovara javno ulaganje u obrazovanje kako bi se utjecalo na postojeće nejednakosti i spriječilo povećanje budućih nejednakosti. Međutim, građani u dijelu zemalja EU-a izražavaju bojazan da besplatno obrazovanje može rezultirati nižom kvalitetom obrazovanja, iako su svjesni toga da plaćanje obrazovanja često znači nejednaki pristup obrazovanju (u pravilu se misli na tercijarno obrazovanje).

Klaster analiza pokazala je da uobičajeni modeli socijalnih država (skandinavski, kontinentalni, anglosaksonski, mediteranski i postsocijalistički) nisu najprikladniji okvir za analizu preferencija redistributivnih mehanizama. Preciznije, izgleda da se u ovom pogledu koherentnim pokazao samo skandinavski model, odnosno da građani u skandinavskim zemljama imaju slične poglede na različite javne politike. Zemlje kontinentalnog i mediteranskog modela raspoređene su u tri klastera, dok su postsocijalističke zemlje prisutne u svih pet klastera. Kao što je i prije konstatirano, postsocijalističke se zemlje ne ponaša- ju kao jedinstveni blok zemalja u pogledu mehanizama redistribucije. Češka, Poljska i Estonija nalaze se u klasterima s pretežito kontinentalno europskim zemalja, dok je Slovačka u klasteru kojim dominiraju skandinavske zemlje. U preostala dva klastera postsocijalističke zemlje su uglavnom izmiješane s južnoeuropskim zemljama.

Treba naglasiti da je Hrvatska u skupini od 10 zemalja EU-a s najvišim redistributivnim preferencijama i s najvećim udjelom građana koji smatraju da su dohodovne nejednakosti u društvu prevelike, iako se prema visini stvarnih dohodovnih nejednakosti nalazi na razini EU prosjeka. Također, za Hrvatsku je svojstven nesrazmjer između visokih redistributivnih preferencija i percepcije vlastitog mjesta na dohodovnoj ljestvici (oko $70 \%$ građana svrstava se u srednje decile). Kako u istraživanju Eurobarometra o mehanizmima redistribucije nisu bili dostupni podaci za Hrvatsku, možemo samo konstatirati da hrvatski građani smatraju kako je naše društvo daleko od ostvarenja načela socijalne pravednosti, koje se eksplicitno spominje među najvišim vrednotama ustavnog poretka i koje većina radništva u Hrvatskoj rangira po važnosti odmah iza vrednota slobode i poštovanja ljudskih prava (Magdalenić, 1998.). To je također razvidno iz podataka Eurobarometra (2018.) koji pokazuju da tek $29 \%$ građana misli kako svi u Hrvatskoj imaju jednake šanse za napredovanje u životu (jedino je manji udio građana bio u Grčkoj), a još manje (24\%) smatra da u našem društvu svatko dobije ono što zasluži (manji udio građana bio je jedino u Grčkoj, Cipru i Latviji).

\section{ZAKLJUČAK}

Kauzalni lanac između dohodovnih nejednakosti i razine redistributivnih preferencija je dugačak, tako da se između ovih varijabli umeće utjecaj brojnih medijatorskih čimbenika (Toth i Keller, 2011.). Ipak, rezultati analize pokazuju da su percepcije 
visokih nejednakosti u društvu povezane $s$ većim redistributivnim preferencijama, sa zahtjevima da vlada treba intervenirati kako bi smanjila dohodovne nejednakosti, s gubitkom povjerenja u načela socijalne pravednosti (jednakost šansi i zasluga) i potporom progresivnijem sustavu oporezivanja. Stvarne dohodovne nejednakosti relativno slabo utječu na distributivne zahtjeve.

Građani u zemljama EU-a često pogrešno percipiraju razinu stvarnih nejednakosti u društvu i svoje mjesto na dohodovnoj ljestvici. Drugim riječima, postoji diskrepancija između percepcije i stvarnih nejednakosti, koja nije karakteristična samo za dohodovne nejednakosti: do sličnih su nalaza došli istraživači u mnogim drugim područjima, kao što su stope kriminala, nasilja, demokratske vladavine, sreće, zaposlenosti, nezaposlenosti itd. (Fatke, 2018.). Pojedinci donose preopćenite zaključke o ekonomskim nejednakostima na temelju svoje neposredne okoline ili referentne grupe, zbog globalnih medija stanovnici u siromašnim zemljama mogu se uspoređivati s onima u bogatima (mediji često doprinose senzacionalizmu, ali mogu i smanjivati pogrešne percepcije nejednakosti kada daju egzaktne brojke ili podatke), na percepcije nejednakosti utječu političke ideologije i vrijednosti sustavi (socijalizam, liberalizam, konzervativizam) te psihološki i drugi faktori (Gimpelson i Treisman, 2018.). Bolja informiranost i veća svijest o dohodovnim nejednakostima u pravilu potiču zahtjeve za redistribucijom.

Socijalističko nasljeđe utječe na percepciju nejednakosti, ali taj utjecaj nije jednak u svim postsocijalističkim zemljama. Općenito, građani u postsocijalističkim zemljama osjetljiviji su na dohodovne nejednakosti i imaju veću »averziju« prema njima. Iako se stavovi građana prema dohodovnim nejednakostima u postsocijalističkim zemljama mijenjaju i približavaju stavovima građana u zapadnim zemljama bez socijalističkog nasljeđa, u svim postsocijalističkim ze- mljama građani žele veću ulogu države u redistribuciji i društvenom životu.

Građani EU-a podržavaju sve ključne mehanizme dohodovne redistribucije (porezi, obrazovanje, socijalna zaštita i minimalna plaća), ali im pridaju različitu važnost. Najveću potporu daju poreznom sustavu i progresivnom oporezivanju bogatijih, dok je najviše dilema vezano za potpuno besplatno obrazovanje. Jedino građani u zemljama skandinavskog socijalnog modela imaju slične poglede na načine smanjivanja dohodovnih nejednakosti, dok se postsocijalističke zemlje ne ponašaju kao jedinstveni blok kada su u pitanju mehanizmi redistribucije.

Ovaj rad ima određena metodološka i spoznajna ograničenja koja su, među ostalim, posljedica korištenja sekundarnih podataka. U budućim istraživanjima treba analizirati ulogu općenito politike plaća u stvaranju dohodovnih nejednakosti (a ne samo minimalne plaće) jer su plaće glavni izvor dohodovnih nejednakosti. Zatim, bilo bi važno utvrditi snagu i smjer povezanosti između redistributivnih preferencija i nejednakosti u ukupnom bogatstvu jer su nejednakosti u bogatstvu u svim zemljama veće nego nejednakosti u dohotku te nejednakosti u bogatstvu rastu brže nego nejednakosti u dohotku. Osim toga, ispitanici često nisu svjesni razlike između koncepata dohotka i bogatstva. Mada se u pitanjima može izričito tražiti izjašnjavanje građana o razini dohodovnih nejednakosti, nije uvijek jasno jesu li ispitanici u svojim odgovorima mislili upravo na nejednakosti u dohotku ili na nejednakosti u bogatstvu.

\section{LITERATURA}

Aidukaite, J. (2009). Old welfare state theories and new welfare regimes in Eastern Europe: Challenges and implications. Communist and Post-Communist Studies, 42(1), 23-39. https:// doi.org/10.1016/j.postcomstud.2009.02.004

Aidukaite, J. (2011). Welfare reforms and socioeconomic trends in the 10 new EU member states of Central and Eastern Europe. Communist and Post-Communist Studies, 44(3), 211-219. https:// doi.org/10.1016/j.postcomstud.2011.07.005 
Alesina, A., \& La Ferrara, E. (2005). Preferences for redistribution in the land of opportunities. Journal of Public Economics, 89(5-6), 897-931. https://doi.org/10.1016/j.jpubeco.2004.05.009

Alt, J., \& Iversen, T. (2017). Inequality, labor market segmentation, and preferences for redistribution. American Journal of Political Science, 61(1), 2136. https://doi.org/10.1111/ajps.12264

Alvaredo, F., Chancel, L., Piketty, T., Saez, E., \& Zucman, G. (2017). The World Inequality Report 2018. World Inequality Lab. Available at http:// wir2018.wid.world/

Atkinson, A. B., Leventi, C., Nolan, B., Sutherland, H., \& Tasseva, I. (2017). Reducing poverty and inequality through tax benefit reform and the minimum wage: The UK as a case study. The Journal of Economic Inequality, 15(4), 303-323. https://doi.org/10.1007/s10888-017-9365-7

Baloban, J., Črpić, G., \& Ježovita, J. (2019). Vrednote u Hrvatskoj od 1999. do 2018. Zagreb: Kršćanska sadašnjost, Katolički bogoslovni fakultet Sveučilišta u Zagrebu, Hrvatsko katoličko sveučilište.

Baloban, J., Nikodem, K., \& Zrinščak, S. (2014). Vrednote u Hrvatskoj i u Europi: komparativna analiza.Zagreb: Kršćanska sadašnjost, Katolički bogoslovni fakultet Sveučilišta u Zagrebu.

Bénabou, R., \& Ok, E. A. (2001). Social mobility and the demand for redistribution: The POUM hypothesis. Quarterly Journal of Economics, 116(2), 447-487. https://doi. org/10.1162/00335530151144078

Cavaille, C., \& Trump, K.-S. (2015). The two facets of social policy preferences. Journal of Politics, 77(1), 146-160. https://doi.org/10.1086/678312

Cerami, A., \& Stubbs, P. (2011). Post-communist welfare capitalisms: Bringing institutions and political agency back in. EIZ Working Papers, No. EIZ-WP-1103. Available at http://papers. ssrn.com/sol3/papers.cfm?abstract_id=1977289

Coady, D., \& Dizioli, A. (2017). Income inequality and education revisited: Persistence, endogeneity, and heterogeneity. IMF Working Paper WP/17/126. Available at https://www.imf.org/ en/Publications/WP/Issues/2017/05/26/Income-Inequality-and-Education-Revisited-Persistence-Endogeneity-and-Heterogeneity-44854

Cruces, G., Perez-Truglia, R., \& Tetaz, M. (2013). Biased perceptions of income distribution and preferences for redistribution: Evidence from a survey experiment. Journal of Public Economics, 98(C), 100-112. https://doi.org/10.1016/j.jpubeco.2012.10.009
Dabla-Norris, E., Kochhar, K., Suphaphiphat, N., Ricka, F., \& Tsounta, E. (2015). Causes and consequences of income inequality: A global perspective. IMF Staff Discussion Note IMF SDN/15/13. Available at https://www.imf.org/ external/pubs/ft/sdn/2015/sdn1513.pdf

Dolenec, D. (2014). Preispitivanje »egalitarnog sindroma« Josipa Županova. Politička misao, 51(4), 41-64. https://hrcak.srce.hr/135833

Engelhardt, C., \& Wagener, A. (2014). Biased perceptions of income inequality and redistribution. CESifo Working Paper No. 4838. Available at https://papers.ssrn.com/sol3/papers.cfm?abstract_id=2463129

Esping-Andersen, G. (1990). The three worlds of welfare capitalism. Princeton, NJ: Princeton University Press.

Eurobarometer. (2010). Poverty and social exclusion - Report. Special Eurobarometer 355. Brussels: TNS Opinion \& Social. Available at https://data.europa.eu/euodp/en/data/dataset/ S888_74_1_EBS355

Eurobarometer. (2018). Fairness, inequality and intergenerational mobility - Report. Special Eurobarometer 471. Brussels: Directorate-General for Communication. Available at http://data.europa. eu/euodp/en/data/dataset/S2166_88_4_471_ ENG

Evans, G. (2000). The continued significance of class voting. Annual Review of Political Science, 3, 401-417. https://doi.org/10.1146/annurev.polisci.3.1.401

Fatke, M. (2018). Inequality perceptions, preferences conducive to redistribution, and the conditioning role of social position. Societies, 8(4), 1-14. https://doi.org/10.3390/soc8040099

Fenger, H. (2007). Welfare regimes in Central and Eastern Europe: Incorporating post-communist countries in a welfare regime typology. Contemporary Issues and Ideas in Social Sciences, 3(2), 1-30. http://hdl.handle.net/1765/34876

Ferrera, M. (1996). The 'Southern model' of welfare in Social Europe. Journal of European Social Policy, 6(1), 17-37. https://doi. org/10.1177/095892879600600102

Fernández-Albertos, J., \& Kuo, A. (2015). Income perception, information, and progressive taxation: Evidence from a survey experiment. Political Science Research and Methods, 6(1), 83-110. https://doi.org/10.1017/psrm.2015.73

Fong, C. (2001). Social preferences, self-interest, and the demand for redistribution. Journal of Public Economics, 82(2), 225-246. https://doi. org/10.1016/S0047-2727(00)00141-9 
Georgiadis, A., \& Manning, A. (2012). Spend it like Beckham? Inequality and redistribution in the UK, 1983-2004. Public Choice, 151(3-4), 537563. https://doi.org/10.1007/s11127-010-9758-7

Gesis. (2017). International social survey programme ISSP 2009 - Social inequality IV. Variable Report, Documentation release 2017/05/23. Leibniz Institute for the Social Sciences. https:// doi.org/10.4232/1.12777

Gijsberts, M. (2002). The legitimation of income inequality in state-socialist and market societies. Acta Sociologica, 45(4), 269-285. https://doi. org/10.1177/000169930204500402

Gimpelson, V., \& Treisman, D. (2018). Misperceiving inequality. Economics \& Politics, 30(1), 27-54. https://doi.org/10.1111/ecpo.12103

Glaeser, E.L., \& Ward, B. (2006). Myths and realities of American political geography. Journal of Economic Perspectives, 20(2), 119-144. https:// doi.org/10.1257/jep.20.2.119

Gurr, T. R. (1970). Why men rebel. Princeton, NJ: Princeton University Press.

Horrigan, M. W., \& Mincy, R. B. (1994.) The minimum wage and earnings and income inequality. In S. Danziger \& P Gottschalk (Eds.), Uneven tides: Rising inequality in America. New York: Russel Sage Foundation.

Johannessen, S. A. (2019). Minimum wage, minimum effect: Minimum wages and income inequality in advanced democracies [Master's thesis]. University of Bergen, Department of Comparative Politics. Available at https://bora.uib.no/ bora-xmlui/bitstream/handle/1956/20027/Master-thesis-_pdf3.pdf?sequence $=1 \&$ is Allowed $=y$

Karadja, M., Mollerstrom, J., \& Seim, D. (2017). Richer (and holier) than thou? The effect of relative income improvements on demand for redistribution. Review of Economics and Statistics, 99(2), 201-212.https://doi.org/10.1162/REST_a_00623

Kenworthy, L., \& McCall, L. (2008). Inequality, public opinion and redistribution. Socio-Economic Review, 6(1), 35-68. https://doi.org/10.1093/ser/ mwm006

Kenworthy, L., \& Pontusson, J. (2005). Rising inequality and the politics of redistribution in affluent countries. Perspectives on Politics, 3(3), 449471. https://doi.org/10.1017/S1537592705050292

Kim, H., Huh, S., Choi, S., \& Lee, Y. (2018). Perceptions of inequality and attitudes towards redistribution in four East Asian welfare states. International Journal of Social Welfare, 27(1), 28-39. https://doi.org/10.1111/ijsw.12266

Klor, E. F., \& Shayo, M. (2010). Social identity and preferences over redistribution. Journal of Pub- lic Economics, 94(3-4), 269-278. https://doi. org/10.1016/j.jpubeco.2009.12.003

Knell, M., \& Stix, H. (2017). Perceptions of inequality. Available at http://www.ecineq.org/ecineq_ nyc17/FILESx2017/CR2/p88.pdf

Kuhn, A. (2016). The subversive nature of inequality: Subjective inequality perceptions and attitudes to social inequality. CESifo Working Paper No. 6023. Available at https://papers.ssrn.com/sol3/ papers.cfm?abstract_id=2829308

Kuziemko, I., Norton, M. I., Saez, E., \& Stantcheva, S. (2015). How elastic are preferences for redistribution? Evidence from randomized survey experiments. American Economic Review, 105(4), 1478-1508. https://doi.org/10.1257/aer.20130360

Luttmer, E. F. P. (2001). Group loyalty and the taste for redistribution. Journal of Political Economy, 109(3), 500-528. https://doi.org/10.1086/321019

Medgyesi, M. (2013). Increasing income inequality and attitudes to inequality: A cohort perspective. Gini Discussion Paper 94. Available at http:// www.gini-research.org/system/uploads/598/ original/94.pdf?1393500304

Meltzer, A. H., \& Richard, S. F. (1981). A rational theory of the size of government. Journal of Political Economy, 89(5), 914-927. https://doi. org/10.1086/261013

Magdalenić, I. (1998). Hrvatsko radništvo i socijalna pravda. Zagreb: Centar za industrijsku demokraciju SSSH, Friedrich-Ebert-Stiftung.

Milanovic, B. (2000). The median-voter hypothesis, income inequality, and income redistribution: An empirical test with the required data. European Journal of Political Economy, 16(3), 367-410. https://doi.org/10.1016/S0176-2680(00)00014-8

Müller, K.-U. (2013). The economic effects of a federal minimum wage in Germany: Empirical studies on its consequences for earnings, income, and employment [Doctoral dissertation]. Freie Universität Berlin. https://doi.org/10.17169/ refubium-5655

Murthi, M., Tiongson, E. R. (2008). Attitudes to equality: The »socialist legacy« revisited. Policy Research Working Paper 4529. Washington: World Bank. Available at http://documents.worldbank.org/curated/en/863871468036251456/Attitudes-to-equality-the-socialist-legacy-revisited

Neesham, C., \& Tache, I. (2010). Is there an East-European social model?. International Journal of Social Economics, 37(5), 344-360. https://doi. org/10.1108/03068291011038936

Nestić, D. (2002). Ekonomske nejednakosti u Hrvatskoj 1973-1998. Financijska teorija i praksa, 26(3), 595-613. https://hrcak.srce.hr/5874 
Nestić, D., \& Blažević Burić, S. (2018). Radnici na minimalnoj plaći i siromaštvo u Hrvatskoj. Revija za socijalnu politiku, 25(3), 235-263. https:// doi.org/10.3935/rsp.v25i3.1547

Niehues, J. (2014). Subjective perceptions of inequality and redistributive preferences: An international comparison. Available at https://pdfs. semanticscholar.org/1fa2/10b6340448329be06aca72950e7ad1105dcc.pdf

Organisation for Economic Co-operation and Development. (2011). Divided we stand: Why inequality keeps rising. Available at https://www. oecd.org/els/soc/dividedwestandwhyinequalitykeepsrising.htm

Piketty, T. (1995). Social mobility and redistributive politics. Quarterly Journal of Economics, 110(3), 551-584. https://doi.org/10.2307/2946692

Piketty, T. (2014). Kapital u 21. stoljeću. Zagreb: Profil.

Piketty, T., \& Saez, E. (2014). Inequality in the long run. Science, 344(6186), 838-843. https://doi. org/10.1126/science.1251936

Poppitz, P. (2018). Biased perceptions? Consolidating cross-country evidence on objective and perceived inequality. Topics in Social Economics. Available at https://www.aeaweb.org/conference/2019/preliminary/paper/EiSdyAe3

Rainer, H., \& Siedler, T. (2008). Subjective income and employment expectations and preferences for redistribution. Economics Letters, 99(3), 449453. https://doi.org/10.1016/j.econlet.2007.09.011

Rözer, J. J., \& Volker, B. (2016). Does income inequality have lasting effects on health and trust? Social Science and Medicine, 149, 37-45. https:// doi.org/10.1016/j.socscimed.2015.11.047

Sapir, A. (2005). Globalization and the reform of European social models. Bruegel Policy Contribution. Available at http://bruegel.org/2005/09/ globalisation-and-the-reform-of-european-social-models/

Sever, I., \& Drezgić, S. (2003). Koncepcija i strategija socijalnih odnosa u hrvatskom društvu - distribucija dohotka i imovine. Ekonomija/Economics, 10(1), 179-201.

Solt, F. (2008). Economic inequality and democratic political engagement. American Journal of Political Science, 52(1), 48-60. https://doi.org/10.1111/ j.1540-5907.2007.00298.x

Šimurina, N., \& Barbić, D. (2017). Porezne promjene i dohodovne nejednakosti u Europskoj uni- ji tijekom financijske krize. Revija za socijalnu politiku, 24(2), 123-142. https://doi.org/10.3935/ rsp.v24i2.1405

Štulhofer, A., \& Burić, I. (2015). Je li egalitarni sindrom samo teorijska fantazija? Empirijski hommage Josipu Županovu. Politička misao, 52(3), 7-31. https://hrcak.srce.hr/154646

Teal, A. (2019). Assessing the impact of minimum wage on income inequality. UGA Journal of Economics, 1(2). Available at http://econjournal.terry.uga.edu/index.php/UGAJUE/article/view/40

Tilly, C. (2003). Inequality, democratization, and de-democratization. Sociological Theory, 21(1), 37-43. https://doi.org/10.1111/1467-9558.00174

Tóth, I. G., \& Keller, T. (2011). Income distributions, inequality perceptions and redistributive claims in European societies. Gini Discussion Paper 7. Available at http://www.gini-research.org/system/uploads/244/original/DP_7_-_Toth_Keller. pdf

Walker, J., Pearce, C., Boe, K., \& Lawson, M. (2019). The power of education to fight inequality. $O x$ fam Briefing Paper, September 2019. Available at https://www.oxfam.org/en/research/power-education-fight-inequality

Wilkinson, R. G., \& Pickett, K. E. (2006). Income inequality and population health: A review and explanation of the evidence. Social Science and Medicine, 62(7), 1768-1784. https://doi. org/10.1016/j.socscimed.2005.08.036

Wolscho, T. W. (2005). Minimum wages and income inequality in the American states, 1960-2000. Research in Social Stratification and Mobility, 23, 343-368. https://doi.org/10.1016/S02765624(05)23011-1

Zilinski, J. (2014). Learning about income inequality: What is the impact of information on perceptions of fairness and preferences for redistribution?. Available at https://papers.ssrn.com/sol3/papers. cfm?abstract_id=2485121

Županov, J. (1977). Sociologija i samoupravljanje. Zagreb: Školska knjiga.

Županov, J. (1993). Dominantne vrijednosti hrvatskog društva. Erasmus, 1(2), 2-7.

Županov, J. (1995). Poslije potopa. Zagreb: Globus.

Županov, J. (2011). Hrvatsko društvo danas - kontinuitet i promjena. Politička misao, 48(3), 1452-163. https://hrcak.srce.hr/74112 


\title{
Summary
}

\section{INCOME INEQUALITIES AND REDISTRIBUTIVE PREFERENCES IN CROATIA AND EU COUNTRIES: MACRO ANALYSIS}

\author{
Zoran Šućur \\ Department of Social Work, Faculty of Law, University of Zagreb \\ Zagreb, Croatia
}

The paper analyses the relationship between income inequalities and redistributive preferences. The objectives have been: determine to which degree income inequalities are associated with redistributive preferences, which are the correlates of redistributive preferences on the macro level and which mechanisms of redistribution have been preferred by citizens in the EU countries. Aggregated data from two special Eurobarometer surveys (2010 and 2018) were used as the data source on redistributive preferences, while macro-statistical indicators were taken from the Eurostat database. Bivariate correlational analyses, linear regression and the cluster analysis were used for data processing. A general finding is that redistributive preferences are high in almost all EU countries. It seems that an increase of income inequalities is not the key factor of high redistributive preferences, but it is the perception of income inequalities and the sensitivity of citizens towards income inequalities. Citizens in the EU countries often incorrectly perceive the level of inequalities in society and their place on the income scale. The respondents from post-socialist countries have a larger "aversion" towards income inequalities and want a stronger role of the government in the redistribution and social life. Inhabitants of the EU countries support all key mechanisms of income redistribution (taxes, education, social protection and minimum wage), but they give the largest support to the tax system and the progressive taxation of the wealthy, while there are a lot of suspicions regarding fully free education.

Key words: income inequalities, redistributive preferences, European Union, redistributive mechanisms, social justice. 